\title{
Long-Term Changes of Aquatic Communities in the Kharbeyskie Lakes
}

\author{
Elena B. Fefilova ${ }^{a}$, Maria A. Baturina ${ }^{a}$, \\ Olga N. Kononova ${ }^{a}$, Olga A. Loskutova ${ }^{a}$, \\ Ludmila G. Khokhlova ${ }^{a}$ and Olga P. Dubovskaya ${ }^{\text {b,c }}$ \\ anstitute of Biology, Komi Scientific Centre, UB RAS \\ 28 Kommunisticheskaya Str., GSP-2, Syktyvkar, 167982, Russia \\ ${ }^{b}$ Institute of Biophysics SB RAS \\ 50/50 Akademgorodok, Krasnoyarsk, 660036, Russia \\ 'Siberian Federal University \\ 79 Svobodny, Krasnoyarsk, 660036, Russia
}

Kharbeyskie Lakes situated on the North-East of the European Russia were sampled. The aim of the present work was to evaluate the changes in the lakes ecosystems which took place during more than 40 years since the first sampling in 1960's. Faunal richness of aquatic communities changed insignificantly under warming climate and low anthropogenic impacts. Nevertheless, the following changes in zooplankton community of the lakes can be considered as the signs of their oligotrophication: the abundance of species indicating oligotrophic water has increased, the abundance of species indicating eutrophy has decreased, the crustacean role comparing the role of rotifers in zooplankton in quantitative terms has grown, faunal coefficients of trophy (E, E/O) have reduced. According to the structural characteristics of zooplankton the large Kharbeyskie lakes are oligotrophic at present. Zoobenthos is more inert community than zooplankton under influence of environmental changes. According to the data on zoobenthic abundance, biomass, composition and structure, the Kharbeyskie Lakes are mesotrophic ecosystems as well as they were in 1968 and 1969. Some dynamic features of the studied aquatic communities indicate a warming influence on the ecosystem of the Kharbeyskie Lakes in the 2000s. These include increasing of abundance and biomass of zooplankton, zoobenthos and some plankton and benthos taxa and the appearance of thermophilic and eutrofication indicating species in zooplankton.

Keywords: freshwater zooplankton, zoobenthos, tundra water ecosysrems, climate warming, trophy.

(c) Siberian Federal University. All rights reserved

* Corresponding author E-mail address: fefilova@ib.komisc.ru 


\title{
Многолетние изменения в сообществах гидробионтов
}

\section{в Харбейских озерах}

\author{
Е.Б. Фефилова ${ }^{\text {*⿻, М.А. Батурина }}{ }^{\text {a }}$, О.Н. Кононова ${ }^{a}$, \\ О.А. Лоскутова ${ }^{\mathrm{a}}$, Л.Г. Хохлова ${ }^{\mathrm{a}}$, О.П. Дубовская ${ }^{б, в}$ \\ ${ }^{a}$ Институт биологии Коми НЦ УрО РАН \\ Россия, 167982, ГСП-2, Сыктывкар, Коммунистическая, 28 \\ ${ }^{6}$ Институт биофизики СО РАН \\ Россия, 660036, Красноярск, Академгородок, 50/50 \\ ${ }^{6}$ Сибирский федеральный университет \\ Россия, 660041, Красноярск, пр. Свободный, 79
}

Были проведень комплекснье гидробиологические исследования Харбейских озер, расположенных на северо-востоке европейской части России. Целью работы была оценка изменений, произошедших в экосистемах этих тундровых водоемов более чем за 40-летний период. Фаунистическое богатство водных сообществ озер в условиях потепления климата и отсутствия прямых антропогенных воздействий в 2009-2012 г2. сохранилось на уровне 1960-х г2. В зоопланктоне исследованных водоемов выявлены признаки их олиготрофикации: численность олиготрофных видов-индикаторов увеличилась, а обилие видов-индикаторов эвтрофирования уменьшилось, роль ракообразных относительно роли коловраток в количественных показателях возросла, фаунистические коэффициенты трофности (E, E/O) снизились. Согласно структурным характеристикам зоопланктона современное состояние крупных озер Харбейской системы соответствует олиготрофному уровню. Сообщество зообентоса проявляло бо́льшую инертность к влиянию изменений среды: его численность и биомасса, состав и структура сохраняются на уровне мезотрофной экосистемы так же, как в 1968-1969 г2. Некоторые проявления многолетней динамики изученных водных сообществ свидетельствуют о наличии влияния потепления климата на экосистему озер в 2000-е г2. К ним относятся: повышение численности и биомассы зоопланктона, зообентоса и некоторых видов и групп беспозвоночных, появление в составе планктона теплолюбивых видов-индикаторов эвтрофирования.

Ключевые слова: пресноводный зоопланктон, зообентос, тундровые водные экосистемы, потепление климата, трофность.

\section{Введение}

Система Харбейских озер расположена на Северо-Востоке Европы в восточной части Большеземельской тундры в Республике Коми. Этот регион отличается суровым резко-континентальным климатом, глубоким и длительным промерзанием почвы и развитием криогенных процессов (Власова,
1976; Гудованый, 2011a). Первые исследования Харбейских озер осуществлялись коллективом гидрохимиков и гидробиологов Коми филиала Академии наук СССР в $1965-$ 1972 гг. Их целью была «оценка продуктивности озер и особенностей экологической системы» (Власова, 1976, с. 5). В результате этих работ были описаны гидрологиче- 
ские и гидрохимические условия обитания гидробионтов в Харбейских озерах в 1965, 1968, 1969 гг., впервые получены сведения об их флоре и фауне, определена интенсивность продукционных и деструкционных процессов в экосистеме (Продуктивность озер..., 1976).

По прошествии более чем сорока лет со времени первых исследований к современному периоду - второму десятилетию XXI века - экологическая ситуация в восточной части Большеземельской тундры изменилась, изменились также приоритетные направления биологических исследований наземных и водных экосистем этого региона. Тяжелые металлы и нефтепродукты, которые распространяются со стороны промышленных зон, остаются для Большеземельской тундры основными загрязняющими веществами (Даувальтер, 2004; Даувальтер, Хлопцева, 2008). Однако признано, что в последние десятилетия их влияние на Воркутинскую тундру несколько ослабевает в связи с сокращением угольной промышленности и закрытием части воркутинских угольных шахт (Даувальтер, 2004). Соответственно, уменьшается интенсивность переноса загрязняющих веществ, происходящего преимущественно с атмосферными осадками. Вместе с тем возможно усиление активности переноса поллютантов через интенсификацию водостока (Verta et al., 1990) за счет совместного воздействия сельскохозяйственного преобразования почв (Archegova, 2007) и увеличения глубины сезонного протаивания грунта, вызванного удлинением и потеплением теплого сезона (Мажитова, Каверин, 2007). Последнее явление связывается с глобальным потеплением климата (Мажитова, Каверин, 2007), которое наиболее выражено в высокоширотных регионах (Serreze et al., 2000; Hickling et al., 2006; Lenoir et al., 2008; Панин и др., 2009; Carter, Schindler, 2012; Belshe et al., 2013).

Изменение температурного режима среды обитания влияет на водные сообщества северных регионов как опосредованно через модификацию экосистем, так и напрямую, перестраивая доминантный комплекс, вызывая биологические инвазии, влияя на фенологию отдельных видов (Rautio, Korhola, 2002; Richardson, 2008; Adrian et al., 2009; Rosset et al., 2010; Carter, Schindler, 2012; Лазарева, Соколова, 2013 и др.). Повышение температуры изменяет скорость биологического круговорота в водных экосистемах, интенсифицирует биологические процессы в них, что определяет повышение их продуктивности и термическое эвтрофирование (Веригин, 1977). При термическом эвтрофировании не происходит поступления в водоемы дополнительного биогенного вещества, но в сообществах гидробионтов наблюдаются изменения, сходные с теми, которые происходят при химическом загрязнении водных экосистем. Наметившаяся в последние десятилетия тенденция к реолиготрофикации озер, приведшая к увеличению разнообразия планктонной фауны и снижению концентрации фитопланктона, в условиях наступающего глобального потепления утрачивает свои позиции (Jeppesen et al., 2005).

Учитывая изменения экологической ситуации в восточной части Большеземельской тундры, произошедшие в последние десятилетия, представляется актуальным сравнение современного состояния экосистемы Харбейских озер с данными первых гидробиологических исследований. Целью настоящей работы было проведение такой сравнительной оценки по биологическим показателям: структурным характеристикам зоопланктонных и донных сообществ. 


\section{Материалы и методы}

Система Харбейских озер находится в междуречье Коротаихи и Большой Роговой в восточной части Большеземельской тундры на расстоянии около 100 км от г. Воркуты. Пункты отбора гидробиологических и гидрохимических проб из озер расположены в пределах географических координат:

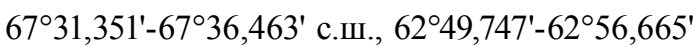
в.д. Сток из Харбейских озер происходит по руч. Харбей-вис через р. Сейда в р. Уса (бас- сейн р. Печора). Из трех наиболее крупных последовательно соединенных водоемов системы нами были исследованы два: оз. Большой Харбей и оз. Головка (рис. 1). Площадь зеркала и максимальная глубина оз. Большой

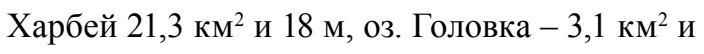
12 м (Власова, 1976). Кроме того, были изучены безымянные более мелкие по площади озера, соединенные протоками с оз. Большой Харбей: К1, Л, Д1, Д2 и К2 (рис. 1). Предположительно обследованные водоемы ледни-

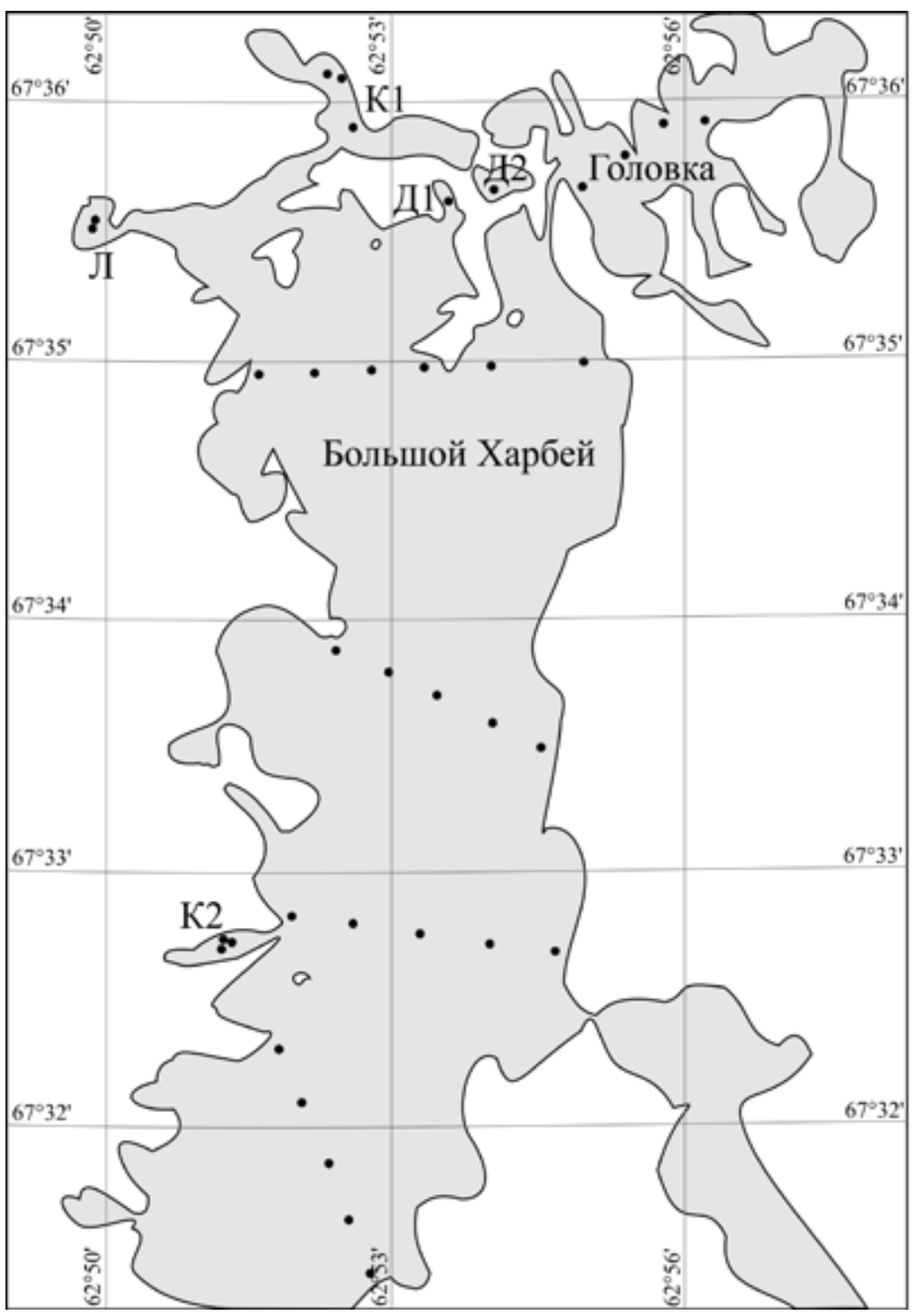

Рис. 1. Карта-схема Харбейских озер. Точками показаны места отбора проб 
ковые по происхождению (Власова, 1976). В прибрежье озер донные субстраты представлены песками, галькой и валунами. В глубоководной части распространены илистые глины (Fefilova et al., 2012).

Материалом для работы послужили пробы зоопланктона и зообентоса, собранные 31 июля - 3 августа 1998 г., 3-5 августа 1999 г., 29 июля - 3 августа 2009 г., 26-28 июля 2010 г. и 29 июля - 7 августа 2012 г., а также архивные данные (журналы разбора проб), относящиеся к концу июля-началу августа 1965 , 1968 и 1969 гг., и опубликованные данные (Барановская, 1976, 1978; Кутикова, 1978; Попова, 1976). Установлен состав гарпактицид из Харбейских озер по пробам 1965 г., предоставленным В.Р. Алексеевым (Зоологический институт РАН).

В 1998 и 1999 гг. собрано 30 количественных проб зоопланктона и 45 проб зообентоса из озер Большой Харбей и Головка. В 2009, 2010 гг. пробы отобраны из озер Большой Харбей, Головка и К2, в 2012 г. - из этих озер и озер: К1, Л, Д1, Д2. В 2009 г. собрано количественных проб: 30 зоопланктона и 30 зообентоса, в 2010 г.: 30 зоопланктона и 29 зообентоса и в 2012 г.: 34 зоопланктона и 42 зообентоса.

Пробы зоопланктона отбирали количественной сетью Джеди, планктобатометром Руттнера или 10-литровым ведром, процеживая объемы воды (50 л) через сеть Апштейна. Во всех сетях использовалось капроновое сито с размером ячеи 80 мкм. Пробы фиксировали 4\%-ным формалином. Камеральную обработку планктонных проб проводили стандартными методами (Методические рекомендации..., 1984). Биомассу животных из планктона и Cladocera, Copepoda из бентоса рассчитывали по формулам связи индивидуальной массы с длиной тела (Ruttner-Kolisko, 1977; Балушкина, Винберг, 1979; Набереж- ный, Ирмашева, 1980). Названия таксонов приведены в соответствии с принятыми в работе (Определитель зоопланктона..., 2010).

Отбор количественных проб зообентоса на мягких грунтах осуществляли дночерпателем Петерсена (с площадью захвата 1/40 $\mathrm{m}^{2}$ ). На небольших глубинах и на плотных грунтах применяли гидробиологический скребок (длина лезвия 0,3 м). Концентрировали пробы зообентоса, промывая их через капроновое сито с размером ячеи 230 мкм. Фиксация проб проводилась 4\%-ным формалином. Массу донных беспозвоночных (кроме Cladocera и Copepoda) после обсушивания на фильтровальной бумаге определяли на торсионных весах WT-250 (Польша). Идентификация до видового статуса беспозвоночных отдельных таксономических групп проводилась в глицериновых препаратах под микроскопом Leica DM 4000 B. Названия таксонов донной фауны приведены в соответствии с принятыми в работах (Определитель пресноводных беспозвоночных..., 1977; Cironomidae of the Holarctic region..., 1983-1989; Определитель пресноводных беспозвоночных России..., 1999; Brooks et al., 2007; Timm, 2009). Авторами статьи были установлены до видового статуса Oligochaeta, Cladocera, Copepoda, Ephemeroptera, Plecoptera, Amphipoda. Определение видового состава Coleoptera проведено Е.К. Роговцовой (Институт биологии Коми НЦ УрО РАН), Chironomidae (по личинкам) Т.А. Кондратьевой (Управление по гидрометеорологии и мониторингу окружающей среды Республики Татарстан).

Параллельно с отбором гидробиологических проб измеряли температуру воды, $\mathrm{pH}$, концентрацию растворенного кислорода (портативным анализатором Multi 340i/ SET, Германия), прозрачность (диском Секки) и отбирали пробы воды для химического анализа. В стационарных условиях определя- 
ли содержащиеся в воде макро- и микроэлементы, органические и биогенные вещества. Анализ химического состава воды выполняли в экоаналитической лаборатории Института биологии Коми НЦ Уральского отделения PAH.

Для сравнения количественных показателей зоопланктона использовали архивные материалы только 1968, 1969 гг., так как в 1965 г. для отбора проб зоопланктона применяли капроновое сито с бо́льшим размером ячеи (Барановская, 1976).

Для оценки изменений в экосистеме использовали отдельные структурные показатели сообществ планктона и бентоса, изменяющиеся при антропогенном эвтрофировании и загрязнении (Попченко, 1987; Яковлев, 2005; Лазарева, 2010; Fefilova, 2011 и др.), а также потеплении климата и термальном эвтрофировании (Beznosov, Suzdaleva, 2004; Лазарева, 2010 и др.).

Для оценки экологического состояния водоемов по структурным показателям зоопланктона рассчитывали индексы доминирования: $\mathrm{I}=\left(\mathrm{p} \times \mathrm{b}^{0,5}\right)^{0,5}$, где $\mathrm{p}-$ встречаемость вида за период исследований (отношение числа проб, в которых встречен данный вид, к общему числу проб, \%), b - средняя биомасса вида (Пидгайко, 1978); коэффициенты трофии $E / O$ и $E$ (Андронникова, 1996) с использованием списков видов-индикаторов из работ Андронниковой (1996) и Сладечека (Sladecek, 1973). Причем индикаторами олиготрофных условий считали олигосапробные виды, а индикаторами эвтрофии - ß- и мезосапробные виды из списков Сладечека (Sladecek, 1973). Для расчета фаунистических коэффициентов трофии учитывали виды-индикаторы Rotifera, Cladocera и Cyclopoida из планктонных и бентосных проб. Доминантные виды и формы зоопланктеров выделяли по относительной численности и биомассе ( $\geq 5$ \% от общего по- казателя). Вид-супердоминант определяли по максимальному значению индекса доминирования (Рогозин, 2001). Соотношение численностей и биомасс ракообразных и коловраток $\left(\mathrm{N}_{\mathrm{Cr}} / \mathrm{N}_{\mathrm{Rot}} ; \mathrm{B}_{\mathrm{Cr}} / \mathrm{B}_{\mathrm{Rot}}\right)$ в зоопланктоне брали для оценки изменчивости размерной структуры сообщества по периодам исследований.

Для характеристики структурных показателей развития зообентоса в исследованных водоемах рассчитывали численность, биомассу, частоту встречаемости (Методика изучения биогеоценозов..., 1975). Для оценки значимости отдельных видов беспозвоночных в донных сообществах и выделения доминирующих комплексов в них использовали индекс доминирования Палия-Ковнацки (Шитиков и др., 2005): $\mathrm{D}=(\mathrm{Q} \times \mathrm{n} \times 100) / \Sigma(\mathrm{Q} \times \mathrm{N})$, где $\mathrm{Q}$ - средняя численность определенного вида в пробе, n - число проб, содержащих данный вид, $\mathrm{N}$ - общее число собранных проб. По значениям индекса гидробионтов зообентоса делили на три группы: доминанты (D = 10-100), субдоминанты $(\mathrm{D}=1,00-9,99)$ и адоминанты $(\mathrm{D}=0,10-0,99)$. Принадлежность вида к определенной трофической группе определяли по Монакову (1998) или Яковлеву (2005). Значения индивидуальной сапробности видов указывали из списков Сладечека (Sladecek, 1973) и других работ (Brinkhurst, Kennedy, 1965; Макрушин, 1974; Lafont, 1984; Milbrink, 1980; Särkkä, 1994; Finogenova, 1996; Зинченко, 2011 и др.). Для характеристики экологического состояния обследованных озер использовали классификацию водоемов по биомассе зообентоса Китаева (2007), информационный индекс сапробности олигохет - Is (Попченко, 1987), определяли соотношение средних масс хищников и мирных организмов $-\mathrm{B}_{\mathrm{x}} / \mathrm{B}_{\mathrm{M}}$, изменение индивидуальной массы организмов в пробах $\mathrm{W}_{\mathrm{cp}}$ (Яковлев, 2005).

Для оценки сходства фаун применяли коэффициент Съеренсена (Sørensen, 1948). 
Достоверность различий средних численности и биомассы зоопланктона и зообентоса, средних индивидуальных масс бентосных организмов в разные годы устанавливали критерием Колмогорова-Смирнова (Лакин, 1990), который рассчитывали с использованием Statistica 6.0 для Windows.

\section{Результаты}

Оиенка изменений условий обитания гидробионтов

Согласно данным, опубликованным в (Гудованый, 2011a), динамика среднемесяч- ных температур воздуха в г. Воркуте за период 1960-2009 гг. имела положительный тренд (рис. 2). Повышение этого показателя составило $2,3{ }^{\circ} \mathrm{C}$. По данным Гудованого (2011a), были получены положительные тренды динамики среднемесячной температуры воздуха в мае и июне (рис. 2). За период 1960-2009 гг. среднемесячная температура воздуха в г. Воркуте в мае повысилась на $2,5^{\circ} \mathrm{C}$, в июне - на $3,5^{\circ} \mathrm{C}$. Так как весенний переход температуры воздуха через $0{ }^{\circ} \mathrm{C}$ в среднем приходится на 28 мая (за период 1937-2009 гг.) (Гудованный, 2011a), а освобождение ото льда аквато-

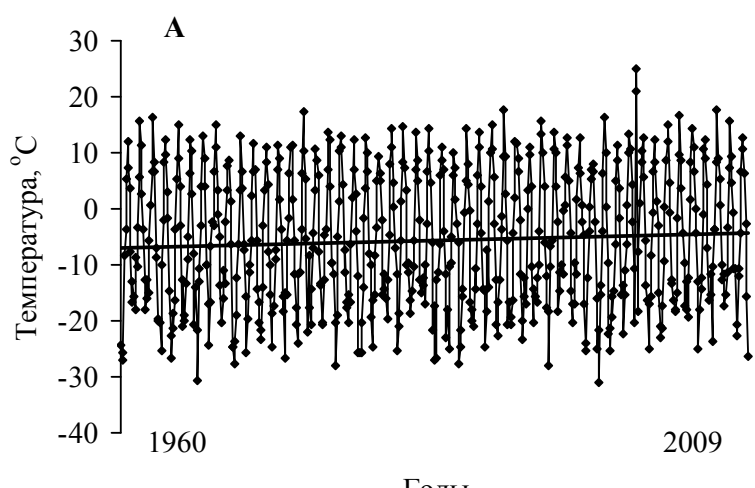

Годы

B

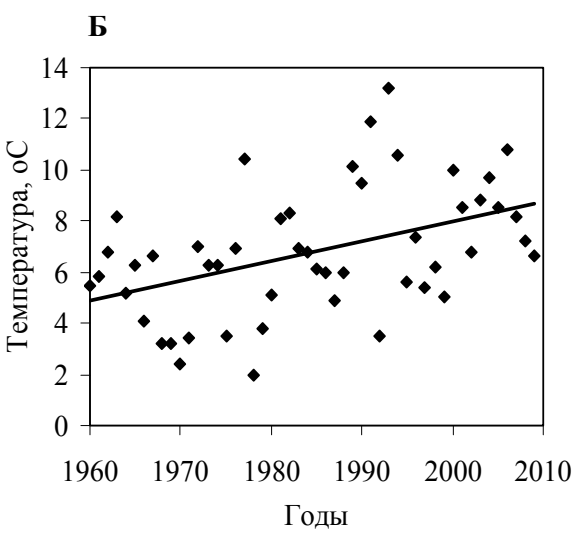

Годы

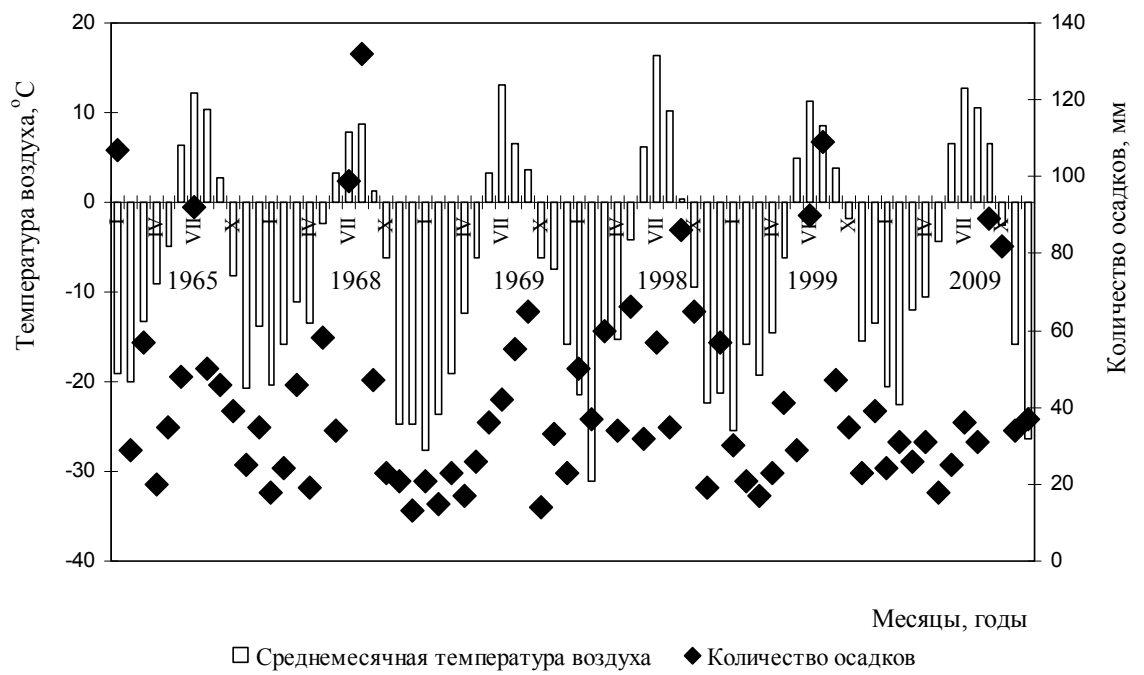

Рис. 2. Динамика среднемесячной температуры воздуха за период 1960-2009 гг. (А), динамика средней за июнь температуры воздуха (Б) и динамика среднемесячной температуры воздуха и количества осадков за месяц в некоторые годы (В) в г. Воркуте, по данным Гудованого (2011a) 
рии Харбейских озер в 1960-е гг. обычно происходило в июне (Власова, 1976), потепление этих месяцев может означать, что сроки начала биологического лета в обследованных водоемах к концу XX - началу XXI в. стали более ранними.

Известно также (Гудованый, 2011а), что 1968 г. в Воркутинском районе характеризовался самым холодным летом за период 19372009 гг., а зима 1968-1969 гг. - экстремально низкими зимними температурами (рис. 2). Весной 1968 г. вскрытие оз. Большой Харбей произошло очень поздно - 9 июля (Власова, 1976). Годы 1965-1998 отличались высокими показателями количества атмосферных осадков (рис. 2), суммы осадков в эти годы превышали среднемноголетний показатель (534 мм (Гудованый, 2011a)). В 1968 г. сумма осадков равнялась этому значению, а в 1969 г. была наименьшей за исследованный период 370 мм (Гудованый, 2011a).

Пределы колебаний температуры воды в Харбейских озерах в периоды наших исследований в 2009 г. составляли 14,1-16,3, в 2010 г. - 8,5-11,7, в 2012 г. $-11,1-16,1^{\circ} \mathrm{C}$. В период отбора проб в 1998 г. температура воды была $18,1-18,7$, а в 1999 г. $-10,6{ }^{\circ} \mathrm{C}$. В годы более ранних полевых сборов температура воды варьировала в 1965 г. - от 12,4-13,9, в 1968 г. - 6,2-10,3 и в 1969 г. $-7,7-8,2{ }^{\circ} \mathrm{C}$ (Власова, 1976).

Не выявлено существенных изменений физических (прозрачность воды) и химических показателей качества воды в Харбейских озерах в 2000-х гг. относительно 1960-х (Fefilova et al., 2012). По гидрохимическим данным, полученным в 2012 г., озера, придаточные по отношению к оз. Большой Харбей, относились к тому же типу вод, что и основные озера Харбейской системы: низкоминерализованные, гидрокарбонатно-кальциевые, с низким содержанием биогенов. Во все годы современных исследований не было выявлено признаков эвтрофирования Харбейских озер по гидрохимическим показателям (Хохлова, 2014).

\section{Изменения зоопланктона}

На современном этапе исследований (2009, 2010, 2012 гг.) в Харбейских озерах обнаружено 98 таксонов зоопланктона: 53 вида и формы коловраток (Rotifera), 27 видов и форм ветвистоусых (Cladocera) и 18 видов и форм веслоногих раков (Сopepoda) отрядов Cyclopoida и Calanoida. Из них индикаторную значимость для определения трофического типа водоемов непосредственно или через их сапробность имеет 41 вид (Sladecek, 1973; Андронникова, 1996). Согласно фаунистическим коэффициентам, рассчитанным по этим видам-индикаторам, в современный период Харбейские озера относились к олиго- или олигомезотрофному типу, а оз. Д2 - к эвтрофному типу (табл. 1). Только в оз. Д2 обнаружена коловратка рода Brachionus (B. nilsoni Ahlstrom), являющаяся индикатором эвтрофирования.

Число установленных таксонов коловраток в Харбейских озерах на современном этапе изучения увеличилось относительно показателя 1968, 1969 гг. (Барановская, 1978; Кутикова, 1978) более чем в три раза. Тогда как число таксонов ракообразных изменилось незначительно: выявлено на пять видов меньше ветвистоусых раков и на два вида больше веслоногих раков в фауне 2000-х гг. по сравнению с 1960-ми (Барановская, 1976, 1978). Различия в фаунистическом богатстве коловраток раннего и современного периодов обследования Харбейских озер обуславливались, прежде всего, несоответствием методик отбора проб и их анализа в эти периоды. Сходство фаун планктонных ракообразных обследованных озер, выявленных ранними и современными 
Таблица 1. Коэффициенты трофии, рассчитанные по видам-индикаторам коловраток и ракообразных для Харбейских озер по данным 2009, 2010, 2012 гг.

\begin{tabular}{l|c|c}
\hline \multicolumn{1}{c|}{ Озера, годы } & $E / O$ & $E$ \\
\hline Харбейские озера, 2009, 2010, 2012 гг. & 0,37 & 0,39 \\
Оз. Большой Харбей, 2009, 2010, 2012 гг. & 0,26 & 0,25 \\
Оз. Большой Харбей, 2012 г. & 0,13 & 0,09 \\
Оз. Головка, 2009, 2010, 2012 гг. & 0,24 & 0,30 \\
Оз. Головка, 2012 г. & 0,13 & 0,22 \\
Оз. К1, 2012 г. & 0,17 & 0,20 \\
Оз. Л, 2012 г. & 0,13 & 0,18 \\
Оз. Д1, 2012 г. & 0,50 & 0,22 \\
Оз. Д2, 2012 г. & 0,50 & 1,20 \\
Оз. К2, 2012 г. & 0,08 & 0,09 \\
\hline
\end{tabular}

исследованиями, определялось коэффициентом Съеренсена 0,78 и было значительным. Различия в количественных и качественных характеристиках их состава между 1960-ми и 2000-ми гг. не превышали таких различий между годами 2009, 2010 и 2012. Коэффициенты Съеренсена, рассчитанные для сравнения фаун планктонных коловраток и ракообразных между 2009, 2010 и 2012 гг., равнялись 0,62-0,68. Сходство состава только ракообразных в 2009, 2010 и 2012 гг. было выше: коэффициенты Съеренсена 0,72-0,75.

В результате исследований определен состав общих видов, присутствовавших в зоопланктоне Харбейских озер в 1960-e, 1990-e (Fefilova et al., 2012) и 2000е гг.: Bipalpus hudsoni (Imhof), Asplanchna priodonta Gosse, Keratella cochlearis (Gosse), K. quadrata (Müller), Kellicottia longispina (Kellicott), Conochilus unicornis Rousselet, Sida crystallina (O.F. Müller), Limnosida frontosa (Sars), Holopedium gibberum Zaddach, Daphnia cristata Sars, Chydorus sphaericus (O.F. Müller), Alonopsis elongatus (Sars), Alona affinis (Leydig), Bosmina sp., Leptodora kindtii (Focke), Cyclops scutifer Sars, Megacyclops viridis (Jurine), Eudiaptomus gracilis Sars и Heterocope appendiculata Sars. Отсутствовали в пробах в отдельные годы, но встречались во все периоды изучения озер: Polyarthra dolichoptera Idelson, Lecane luna (Müller), L. (Monostyla) lunaris (Ehrenberg), Filinia terminalis (Plate).

Численность и доля в численности 30опланктона некоторых из этих видов сохранялась во все исследуемые периоды (табл. 2). Были одинаково многочисленны и/или доминировали в зоопланктоне по численности в 1960-2000-е гг.: K. cochlearis, K. longispina; оставались малочисленными: B. hudsoni, L. frontosa, H. gibberum, Ch. sphaericus, C. scutifer, E. gracilis, H. appendiculata. Доля в численности зоопланктона и обилие самого массового вида - C. unicornis - увеличилась в 2000-х гг. относительно ранних периодов исследований, а K. quadrata на современном этапе исследований встречалась в оз. Головка (Fefilova et al., 2012), но не в оз. Большой Харбей. По сравнению с 1960-ми к 2000-м годам в Харбейских озерах снизилась относительная численность A. priodonta, F. terminalis и B. longirostris (табл. 2). Снижение относительной и средней численности B. longirostris в обследованном водоеме может быть показателем понижения уровня трофности экосисте- 
Таблица 2. Динамика численности некоторых видов в оз. Большой Харбей, встречающихся во все периоды исследований, в конце июля - начале августа

\begin{tabular}{|c|c|c|c|c|c|c|}
\hline \multirow{3}{*}{ Вид или род } & \multicolumn{6}{|c|}{ Относительная (\%) и средняя (тыс. экз/м³) численность в зоопланктоне } \\
\hline & \multicolumn{2}{|c|}{ 1960-е гг. } & \multicolumn{2}{|c|}{ 1990-е гг. } & \multicolumn{2}{|c|}{2000 -е гг. } \\
\hline & $\%$ & тыс. экз/ $\mathrm{M}^{3}$ & $\%$ & тыс. экз/ $\mathrm{M}^{3}$ & $\%$ & тыс. экз/ $\mathrm{M}^{3}$ \\
\hline B. hudsoni & $<1$ & $0,6 \pm 0,2$ & $<1$ & $0,2 \pm 0,07$ & $<1$ & $0,02 \pm 0,007$ \\
\hline A. priodonta & 21 & $18 \pm 14$ & 1 & $1,3 \pm 0,4$ & 1 & $1,5 \pm 0,3$ \\
\hline K. cochlearis & 11 & $10 \pm 4$ & 2 & $2,5 \pm 0,7$ & 6 & $10 \pm 2$ \\
\hline K. quadrata & 1 & $0,7 \pm 0,2$ & $<1$ & $0,2 \pm 0,09$ & 0 & 0 \\
\hline K. longispina & 20 & $17,6 \pm 3$ & 29 & $33 \pm 5,6$ & 20 & $29 \pm 2$ \\
\hline C. unicornis & 11 & $9,7 \pm 3$ & 36 & $41 \pm 10$ & 52 & $70 \pm 7$ \\
\hline F. terminalis & 5 & $4,7 \pm 2,7$ & 2 & $2,3 \pm 0,7$ & $<1$ & $1 \pm 0,3$ \\
\hline L. frontosa & $<1$ & $* *$ & $<1$ & $0,2 \pm 0,1$ & $<1$ & $0,4 \pm 0,1$ \\
\hline H. gibberum & 1 & $0,7 \pm 0,1$ & 3 & $3,4 \pm 0,7$ & 1 & $1 \pm 0,2$ \\
\hline Daphnia & $<1$ & $0,2 \pm 0,05$ & 2 & $2 \pm 0,6$ & 2 & $3 \pm 0,4$ \\
\hline B. longirostris & 1 & $1 \pm 0,2$ & 2 & $2 \pm 0,7$ & $<1$ & $0,06 \pm 0,03$ \\
\hline B. longispina & - & - & 2 & $2 \pm 1$ & 5 & $8 \pm 2$ \\
\hline Ch. sphaericus & 1 & $0,9 \pm 0,1$ & $<1$ & $0,7 \pm 0,2$ & 1 & $2 \pm 0,2$ \\
\hline C. scutifer & $<1$ & $0,2 \pm 0,1$ & 1 & $1,2 \pm 0,4$ & 1 & $1,5 \pm 0,2$ \\
\hline E. gracilis & $<1$ & $0,02 \pm 0,01$ & $<1$ & $0,1 \pm 0,07$ & $<1$ & $0,4 \pm 0,06$ \\
\hline H. appendiculata & $<1$ & $0,1 \pm 0,08$ & $<1$ & $0,7 \pm 0,3$ & $<1$ & $0,7 \pm 0,1$ \\
\hline
\end{tabular}

Примечание: - вид не был идентифицирован; ** несколько особей встречены в качественной пробе.

мы, так как данный вид известен в качестве индикатора эвтрофирования (Андронникова, 1980, 1996; Лазарева, 2010; Смирнов, 2010 и др.). Кроме того, показателем деэвтрофирования озер может служить увеличение роли Daphnia в планктонных сообществах (Dupuis, Hann, 2009; Лазарева, 2010 и др.), хотя и не всех видов. Например, встречающаяся в 1990е и 2000-е гг. в Харбейских озерах Daphnia cucullata Sars является индикатором мезо- и эвтрофных условий (Андронникова, 1996). Однако роль этого вида в суммарном обилии обнаруженных нами пяти представителей рода и вклад в динамику численности всех Daphnia были очень малы (Fefilova et al., 2012). Как D. cucullata, другой индикатор эвтрофирования и теплолюбивый вид, Polyarthra euryptera Wierzejski, единично встречался в зоопланктоне озер в 1999, 2009, 2010 гг. В
2012 г. оба вида «выпали» из состава планктонной фауны Харбейских озер, но только в этом году в озерах Большой Харбей, Головка, Д1 и К2 был отмечен неидентифицированный до вида Bythotrephes, присутствие которого, как известно (Андронникова, 1996), указывает на олиготрофные условия.

Только в 1960-е гг. в Харбейских озерах отмечалось разнообразие родов Ceriodaphnia и Alonella (Барановская, 1976). Поскольку место обнаружения видов этих фитофильных родов автором не уточнялось, можно предположить, что они были найдены (и до сих пор обитают) в не обследованных нами придаточных по отношению к оз. Большой Харбей озеpax, вероятно, в зарослях макрофитов.

Средняя численность зоопланктона в оз. Большой Харбей в конце июля, начале августа в 2009-2012 гг. составляла 


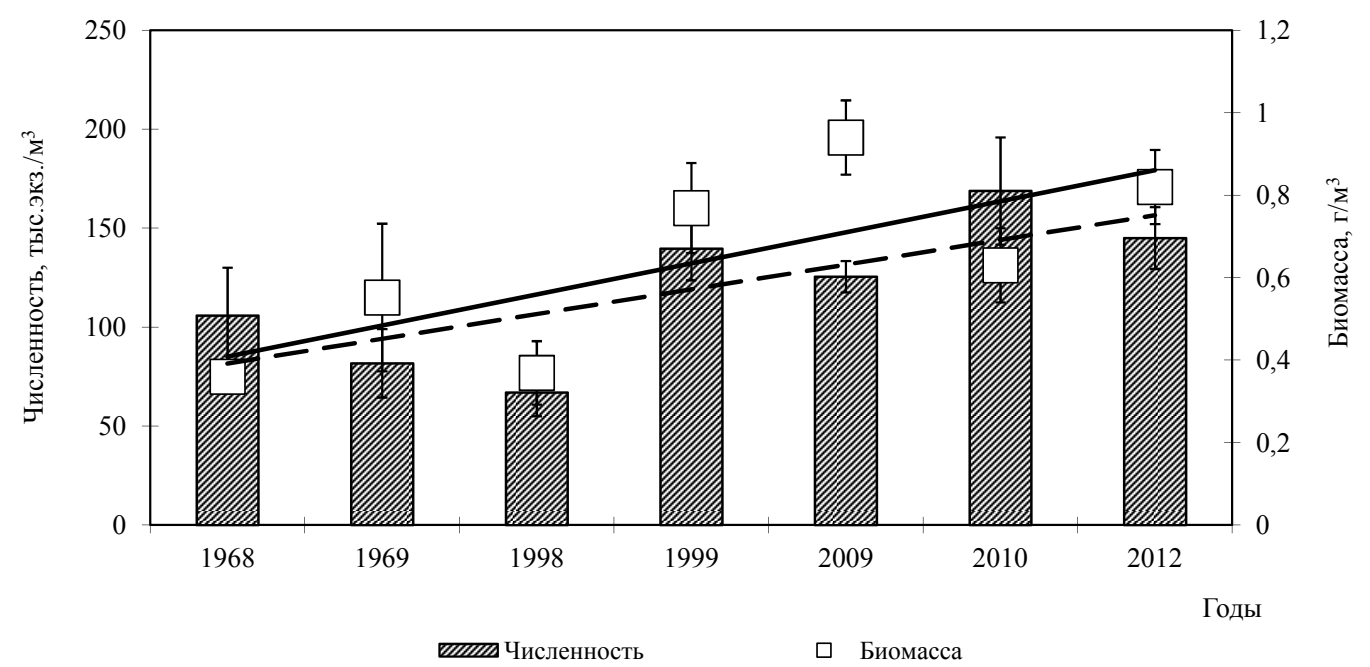

Рис. 3. Изменение средних численности и биомассы зоопланктона в оз. Большой Харбей в конце июля, начале августа. Пунктирная линия - тренд численности, сплошная линия - тренд биомассы

$(144 \pm 9)$ тыс. экз $/ \mathrm{M}^{3}$. Достоверные различия $(\mathrm{p}<0,05)$ обнаружены в численности зоопланктона только между 1969 г. и годами позже и между 1998 г. и годами позже. Тренд изменения численности в конце июля - начале августа за период 1968-2012 гг. был положителен (рис. 3). В 2000-е гг., как в 1960-е (Барановская, 1976), обилие зоопланктона в оз. Головка было выше, чем в оз. Большой Харбей и составляло (262 \pm 30) тыс. экз/м³. В озерах К1 и Л показатели средней численности зоопланктона в 2012 г. составляли соответственно $(98 \pm 28)$ и (277 \pm 90$)$ тыс. экз/м². Для 0з. К1 этот показатель был ниже по сравнению со значением 1968 г. в семь раз, со значением 1969 г. - в три раза (Барановская, 1976); численность зоопланктона в оз. Л соответствовала в 2012 г. показателям 1968, 1969 гг. (Барановская, 1976). Высокая численность животного планктона зарегистрирована в 2012 г. в оз. Д2: 2572 тыс. экз/м². Этот показатель почти в два раза превышал также высокие значения обилия зоопланктона, полученные в 1960-е гг. для оз. Гаммарусовое Харбейской системы, сообщающеегося с о3. Большой Харбей длинной протокой (Бара- новская, 1976). Как и в 1960-е гг. (Барановская, 1976), на современном этапе исследований в зоопланктоне оз. Большой Харбей и Головка в летнее время доминировали по численности коловратки.

Отношение численности ракообразных к численности коловраток составляло в 20092012 гг. в оз. Большой Харбей - $22 \%$, в оз. Головка - 26 \%. В 1968 - 1969 гг. для оз. Большой Харбей этот показатель составлял $21 \%$, а в 1998-1999 гг. $-27 \%$.

Средняя биомасса зоопланктона в оз. Большой Харбей в конце июля, начале августа в 2009-2012 гг. составляла $(0,72 \pm 0,05)$ г/Mㄹ. Как и тренд изменений средней численности, тренд динамики биомассы в озере за весь период его изучения был положителен (рис. 3), и в большинстве случаев межгодовые различия биомассы были достоверны $(\mathrm{p}<0,05)$. Средняя биомасса зоопланктона в оз. Голов-

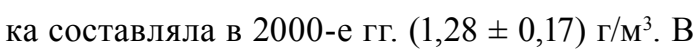
других придаточных по отношению к Большому Харбею озерах в этот период данный показатель варьировал от $(0,50 \pm 0,07)$ в

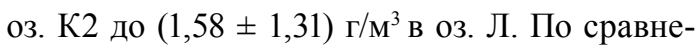




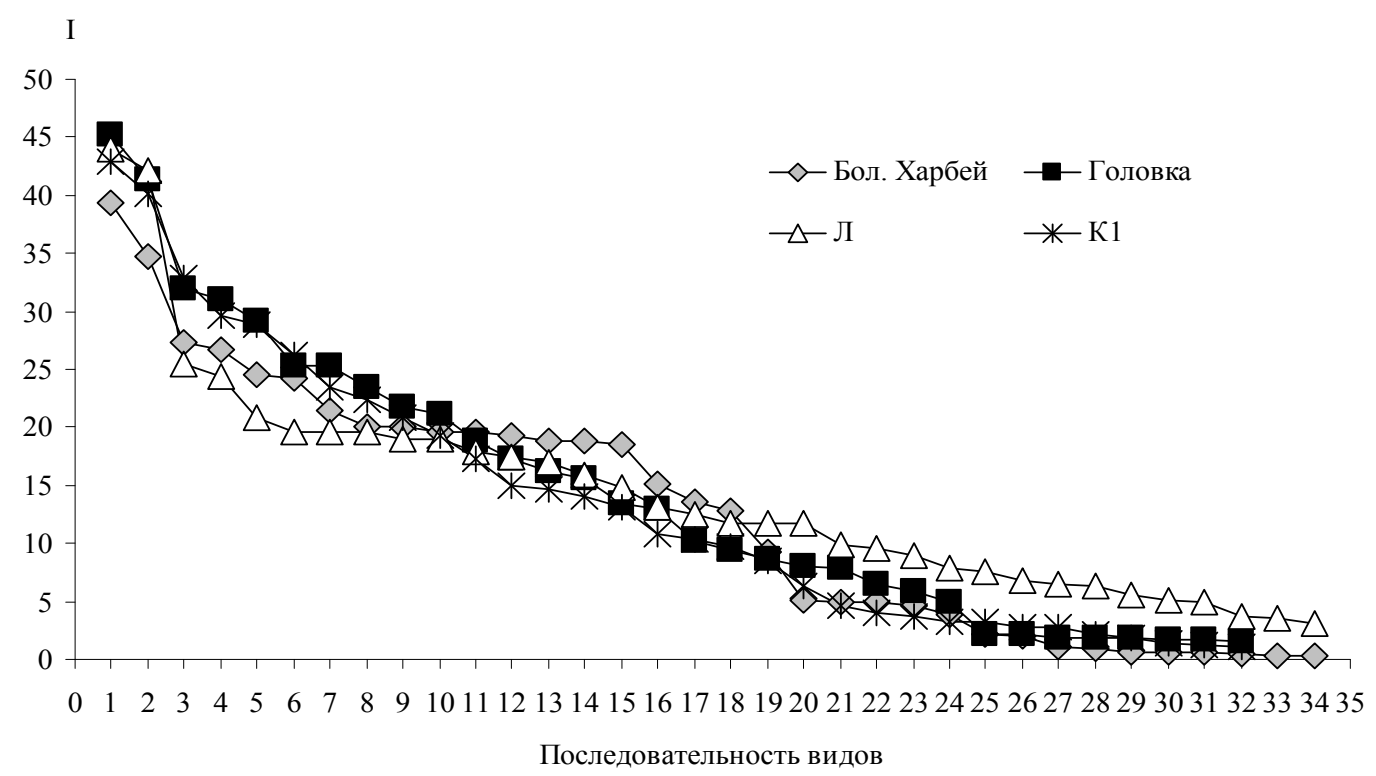

Рис. 4. Ранговое распределение индекса доминирования по биомассе (I) видов зоопланктона в Харбейских озерах в 2012 г.

нию со значениями биомассы (Барановская, 1976), полученными в наиболее ранний период обследования придаточных Харбейских озер, показатели биомассы зоопланктона в 2000-е гг. не изменились.

Для определения экологического состояния обследованных озер были ранжированы индексы доминирования видов и форм зоопланктона по биомассе (рис. 4). Результаты аппроксимации данных зависимостей приведены в табл. 3. Кривые ранжирования почти совпадают для озер Большой Харбей, Головка и меньших по площади озер Харбейской системы в 2012 г. (рис. 4). Константы $a$ изменялись по годам и периодам исследований в Харбейских озерах несущественно (табл. 3; Fefilova et al. 2012). В целом пологие формы кривых ранжирования индексов доминирования и значения констант $a$ свидетельствовали о стабильности и благополучии сообществ зоопланктона и, следовательно, экосистемы Харбейских озер в разные периоды ее обследования на протяжении более чем 40 лет. В
2012 г. видами супердоминантами по биомассе (им соответствуют верхние значения индексов доминирования на кривых ранжирования (рис. 4)) в зоопланктоне изученных водоемов оказались: в оз. Большой Харбей и оз. К1 H. appendiculata, оз. Головка - C. sphaericus, оз. Л - фитофильный S. crystallina и - на втором месте - B. longispina. В 1960-е и 1990-е гг. «видами» супердоминантами по биомассе в оз. Большой Харбей были K. longispina, A. priodonta, H. appendiculata и Calanoida sp. juv. (Fefilova et al., 2012).

\section{Изменения зообентоса}

В составе донной фауны оз. Большой Харбей в 2009, 2010, 2012 гг. обнаружено 23 таксономические группы беспозвоночных. Все они характерны для стоячих водоемов Большеземельской тундры (Зверева, 1966; Лоскутова, 2002; Fefilova et al., 2008) и отмечались в Харбейских озерах ранее (Попова, 1976; Лоскутова, 2002). В 2000-х гг. самыми распространенными организмами в бентосе оз. Большой 
Таблица 3. Величины константы $a$ экспоненциальных уравнений, описывающих кривые доминирования по биомассе видов зоопланктона в Харбейских озерах (см. рис. 4)

\begin{tabular}{c|c|c|c}
\hline Озеро & Год & $a$ & $R^{2}$ \\
\hline \multirow{2}{*}{ Оз. Большой Харбей } & 2010 & 51,5 & 0,99 \\
& 2012 & 79,4 & 0,90 \\
Оз. Головка & 2010 & 54,3 & 0,96 \\
Оз. К1 & 2012 & 59,9 & 0,95 \\
Оз. Л & 2012 & 43,4 & 0,91 \\
\hline
\end{tabular}

Примечание. $R^{2}$ - коэффициент детерминации.

Харбей были личинки Chironomidae и низшие ракообразные: Cladocera и Copepoda, которые встречались в 80-100 \% проб зообентоса. Высокой частотой встречаемости отличались черви (Nematoda, Oligochaeta) и моллюски (Mollusca). Гораздо реже (менее чем в $10 \%$ проб) наблюдали в зообентосе Hydrozoa, личинок насекомых (кроме хирономид) и пиявок (Hirudinea).

Согласно далеко не полному систематическому списку современная фауна донного сообщества оз. Большой Харбей насчитывает более 120 видов беспозвоночных. Из них 52 вида имеют индикаторную значимость. К $\alpha$ - или $\beta$-мезосапробам (а следовательно, индикаторам мезо- и эвтрофных условий (Андроникова, 1996)) относятся 16 видов олигохет и доминирующие виды хирономид (Paratanytarsus austriacus (Kieffer) и Stictochironomus rosenschoeldi (Zetterstedt)), три вида из этих же таксонов - Limnodrilus hoffmeisteri Claperède, Tubifex tubifex (Müller) и Chironomus plumosus (Linnaeus) - известны как полисапробы. Олигохеты: Slavina appendiculata (Udekem), Nais pseudobtusa (Piguet), N. bretscheri Michaelsen, N. behningi Michaelsen, Limnodrilus profundicola (Verrill) и Stylodrilus heringianus Claparède, ракообразные: Eurycercus lamellatus (O.F. Müller), Acroperus harpae (Baird) и Paracyclops fimbriatus (Fischer), и менее четверти обнаруженных нами видов хирономид являются видами-индикаторами олиготрофных условий.

Сходство фаун по коэффициенту Съеренсена внутри доминирующих в зообентосе групп - Oligochaeta, Chironomidae и Crustacea (Cladocera, Copepoda) - в 1960-х, 1990-х и 2000-х гг. составляло более 50 \%. Для фаун Oligochaeta значение этого коэффициента равнялось 0,53-0,62, Chironomidae - 0,50, Copepoda (Cyclopoida и Harpacticoida) - 0,720,85, Cladocera - более 0,90. Причем коэффициенты сходства фаун олигохет и хирономид, возможно, оказались занижены по причине существенного различия методик идентификации видов этих животных в разные периоды исследований. Реликтовый вид Pallasea quadrispinosa G.O. Sars, установленный в составе донной фауны оз. Большой Харбей в 1960-е гг., в 2000 гг. продолжает оставаться единственным представителем Amphipoda в оз. Большой Харбей.

По сравнению с предыдущими периодами наблюдений на современном этапе исследований в оз. Большой Харбей в сходные сроки (конец июля - начало августа) отмечалась более высокая численность зообентоса (табл. 4; рис. 5). Средний за 2009, 2010, 2012 гг. показатель составил $(12,0 \pm 1,8)$ тыс. экз/ $\mathrm{M}^{2}$, 
Таблица 4. Динамика средних численности $\left(\mathrm{N}_{\mathrm{cp}}\right)$ и биомассы $\left(\mathrm{B}_{\mathrm{cp}}\right)$ зообентоса в Харбейских озерах в конце июля - начале августа

\begin{tabular}{|c|c|c|c|}
\hline Озера, годы & $\mathrm{N}_{\mathrm{cp}}$, тыс. экз $/ \mathrm{M}^{2}$ & $\mathrm{~B}_{\mathrm{cp}}, \Gamma / \mathrm{M}^{2}$ & $\begin{array}{c}\text { Лимнологический тип } \\
\text { по Китаеву (2007) }\end{array}$ \\
\hline Оз. Большой Харбей, 1960-е гг. & 6,5 & 4,6 & $\alpha$-мезотрофный \\
\hline Оз. Большой Харбей, 1990-е гг. & $9,6 \pm 1,6$ & $6,1 \pm 0,9$ & $\beta$-мезотрофный \\
\hline Оз. Большой Харбей, 2000-е гг. & $12,7 \pm 1,5$ & $4,1 \pm 0,6$ & $\alpha$-мезотрофный \\
\hline Оз. Головка, 1990-е гг. & $13,7 \pm 4,5$ & $4,3 \pm 2,1$ & $\alpha$-мезотрофный \\
\hline Оз. Головка, 2000-е гг. & $22,6 \pm 4,8$ & $7,7 \pm 1,5$ & $\beta$-мезотрофный \\
\hline Оз. К1, 2012 г. & $14,8 \pm 3,9$ & $6,1 \pm 1,3$ & $\beta$-мезотрофный \\
\hline Оз. Л, 2012 г. & $6,4 \pm 2,3$ & $4,8 \pm 2,2$ & $\beta$-мезотрофный \\
\hline Оз. Д1, 2012 г. & $8,0 \pm 5,1$ & $9,4 \pm 1,5$ & $\beta$-мезотрофный \\
\hline Оз. Д2, 2012 г. & $52,1 \pm 9,6$ & $17,7 \pm 0,3$ & $\alpha$-эвтрофный \\
\hline Оз. К2, 2012 г. & $13,4 \pm 6,6$ & $4,9 \pm 1,3$ & $\beta$-мезотрофный \\
\hline
\end{tabular}

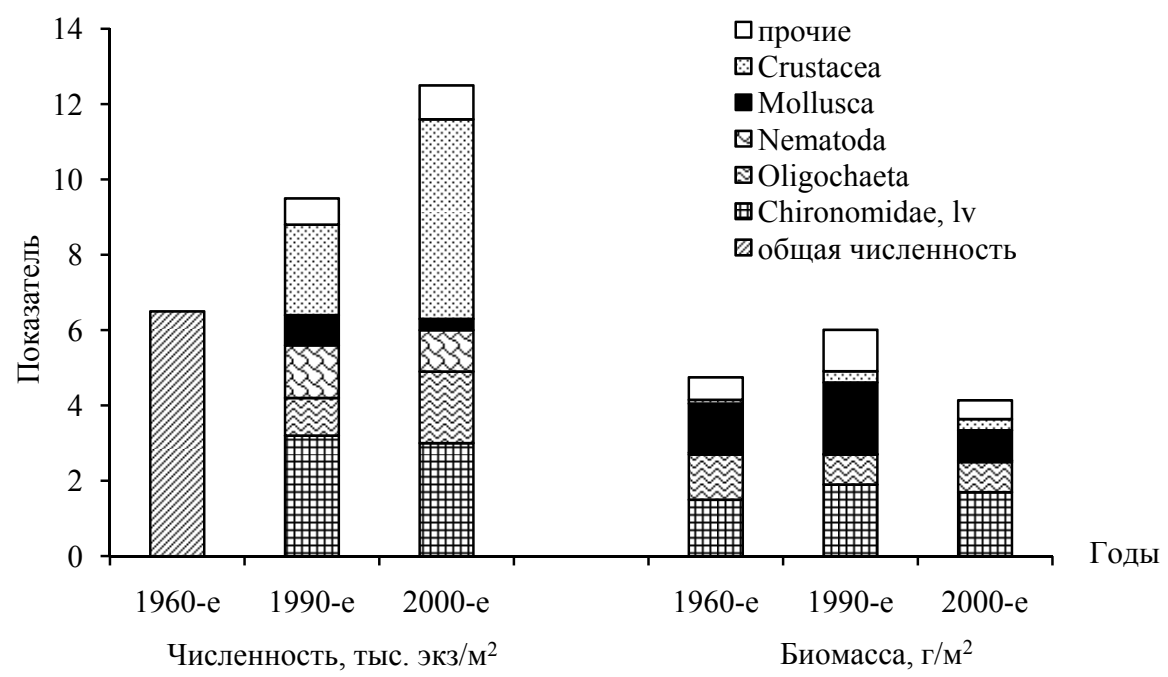

Рис. 5. Изменение численности (тыс. экз/ $\left.\mathbf{M}^{2}\right)$ и биомассы $\left(г / \mathrm{M}^{2}\right)$ доминирующих групп и общей численности и биомассы зообентоса в оз. Большой Харбей в конце июля - начале августа

что в два раза превышает значение средней численности зообентоса в 1960-е гг. Из придаточных водоемов в 2000-е гг. наиболее богатым по численности зообентоса оказалось оз. Д2 (табл. 4).

Как и ранее (Попова, 1976), в период современных исследований 90 \% общей численности зообентоса в оз. Большой Харбей формировали личинки Chironomidae, низшие ракообразные (Cladocera, Copepoda) и черви (Oligochaeta, реже Nematoda) (рис. 5). По сравнению с 1990-ми гг. средняя численность низших ракообразных достоверно $(\mathrm{p}<0,01)$ возросла почти в 2 раза в 2000-х гг. Численность рачкового бентоса в обследованном озере на 46-54 \% была составлена ветвистоусыми раками, остальную долю занимали Cyclopoida и Harpacticoida. 
В 2000-х гг. к числу доминирующих по численности (D до 21,9) в зообентоce оз. Большой Харбей относились виды Chironomidae: $P$. austriacus и $S$. rosenschoeldi, предпочитающие мезотрофные условия (The Chironomidae..., 1995). По соотношению числа видов в подсемействах Orthocladiinae и Chironominae (Зинченко, 2011) обследованное озеро характеризовалось как олиготрофная лимническая система.

Олигохеты, являясь одной из ведущих групп зообентоса в оз. Большой Харбей, составляли в разные годы современного периода исследований от 12,8 до 17,5 \% его численности. В 2000-е гг. состав доминирующего комплекса малощетинковых червей в оз. Большой Харбей оказался сходен с таковым в 1990-е гг. К числу доминантов среди малощетинковых червей $(\mathrm{D}=10,2-22,2)$ в 1990-е и 2000 -е гг. относился $\beta$-мезосапробный Spirosperma ferox Eisen, а в 1999 г. - еще и полисапробный T. tubifex ( $\mathrm{D}=19,2)$. Общим для обоих периодов исследований видом-субдоминантом был Uncinais uncinata (Oersted). В разные годы к доминирующему комплексу олигохет присоединялись субдоминантные: Chernosvitoviella sp. (2000-е гг.), Enchytraeidae sp., Nais pseudobtusa Piguet и Lumbriculus variegatus (Müller) (1990е гг.). Более высокие показатели численности олигохет в сходные сроки 2000-х гг. по сравнению с 1990-ми (рис. 5) определялись ростом численности всех семейств, особенно в прибрежной зоне (в 1,7 раза) на разнообразных типах грунта, зачастую с наличием моховых или водорослевых обрастаний. В целом на всех биотопах увеличивалось количество особей доминирующих видов, помимо этого среди наидид в 2000-х гг. отмечалась высокая численность и разнообразие видов рода Nais, среди тубифицид - неполовозрелой молоди. Значение информационного индекса сапробности олигохет $\left(\mathrm{I}_{\mathrm{s}}\right)$, рассчитанного для оз. Большой Харбей, в 2000-е гг. исследований было 0,25, в 1990-е гг. - 0,32, т. е. практически не изменилось (Попченко, 1987).

Средняя биомасса зообентоса в оз. Большой Харбей в период современных исследований равнялась $(4,0 \pm 0,6)$ г/м². Этот показатель был сравним со значением, полученным в 1960-е гг., и в 1,4 раза достоверно снизился $(\mathrm{p}<0,025)$ относительно 1990-х гг. Во все периоды исследований по биомассе в озере преобладали личинки хирономид, моллюски, олигохеты (рис. 5), реже амфиподы и личинки двукрылых (кроме хирономид), основная доля (29-52 \%) приходилась на личинок хирономид. Общая биомасса зообентоса в водоеме определяется индивидуальной массой гидробионтов $\left(\mathrm{W}_{\mathrm{cp}}\right)$. В 2000-е гг. этот показатель достоверно снижался $(\mathrm{p}<0,001)$ по сравнению с 1990 -ми с $(1,5 \pm 0,3)$ до $(1,1 \pm 0,3)$ мг для всего бентоса и с $(2,8 \pm 0,6)$ до $(2,0 \pm 0,5)$ мг - только для макрозообентоса. Уменьшение биомассы зообентоса в 2009-2012 гг. произошло за счет снижения индивидуальной массы особей как в литорали, так и в профундали озеpa $(\mathrm{p}<0,001)$. Среди придаточных водоемов оз. Д2 выделялось наибольшими показателями биомассы (табл. 4) и наименьшей из всех исследованных водоемов средней индивидуальной массой особей $(0,3 \pm 0,1)$. Основу биомассы бентоса в оз. Д2 составляли низшие ракообразные и личинки хирономид - $(43,9$ и $54,3 \%$ от общего значения соответственно. По величине биомассы зообентоса Харбейские озера в соответствии с классификацией Китаева (2007) на современном этапе изучения относились к $\alpha$-мезотрофному (основное озеро) или $\beta$-мезотрофному (придаточные озера) и $\alpha$-эвтрофному (оз. Д2) типам (табл. 4).

Изменение структуры зообентоса со сменой соотношения трофических группировок может происходить под влиянием антропогенных факторов и являться тенденцией 
Таблица 5. Динамика соотношения биомасс хищного и мирного бентоса $\left(\mathrm{B}_{\mathrm{x}} / \mathrm{B}_{\mathrm{M}}\right)$ в оз. Большой Харбей

\begin{tabular}{|c|c|c|}
\hline Биомасса & 1960-е гг.* & 2000-е гг. \\
\hline Хищный бентос $\left(\mathrm{B}_{\mathrm{x}}, \Gamma / \mathrm{M}^{2}\right)$ & 0,28 & 0,2 \\
\hline Мирный бентос $\left(\mathrm{B}_{\mathrm{M}}, \Gamma / \mathrm{M}^{2}\right)$ & 4,38 & 3,9 \\
\hline $\mathrm{B}_{\mathrm{x}} / \mathrm{B}_{\mathrm{M}}$ & 0,06 & 0,05 \\
\hline
\end{tabular}

Примечание: * По данным Поповой (1976).

устойчивых перестроек в сообществе (Яковлев, 2005). В оз. Большой Харбей отношение биомасс хищного $\left(\mathrm{B}_{\mathrm{x}}\right)$ и мирного $\left(\mathrm{B}_{\mathrm{m}}\right)$ бентоса оказалось сопоставимым для разных периодов исследований (табл. 5). Доля хищных животных (хищные хирономиды, клещи, некоторые ракообразные (Cyclopoida), пиявки, гидры, личинки нехирономидных насекомых) в 1968-1969 гг. в бентосе озера составляла 6 \% его общей биомассы. В 2000-е гг. доля хищных беспозвоночных в биомассе донного сообщества равнялась 5,8 \%.

Были получены интересные закономерности динамики структуры популяций гарпактицид в оз. Большой Харбей, связанные, на наш взгляд, с температурными условиями, обусловливающими их биологические и фенологические особенности. Так, во все годы, когда идентифицировали гарпактицид, кроме 1998 г., в пробах зообентоса присутствовали самки с яйцевыми мешками массовых видов: Paracamptus schmeili (Mrazek), Bryocamptus (Rheocamptus) zschokkei komi Borutzky, Moraria duthiei (Scott), M. schmeili Van Douwe. Доля проб, содержащих таких самок, была в эти годы довольно высокой и составляла $56-76$ \% от числа содержащих Harpacticoida проб. Наряду с самками с яйцевыми мешками четырех массовых видов в пробах регулярно встречались попарно сцепленные для копуляции самки и самцы B. z. komi. Эти наблюдения свидетельствовали о высокой репродуктивной активности гарпактицид в обследованном водоеме в июле-августе, которая характерна на севере для этого периода (Fefilova, 2007). В наиболее теплый за период наших исследований 1998 г. (температура воды более $18{ }^{\circ} \mathrm{C}$ ) в оз. Большой Харбей не было встречено ни одной самки гарпактицид с яйцевым мешком, хотя попарно сцепленные B. z. komi в пробах присутствовали, а численность Harpacticoida в этом году была в два раза выше ( $<$ 0,05), чем в «холодные» 1999 , 2010 гг. Возможно, что влияние температуры на биологические циклы гарпатициды в оз. Большой Харбей в этом году было стимулирующим и массовые виды рано их завершили. Мы, однако, склоняемся к заключению, что высокая для озера температура воды негативно повлияла на физиологическую способность рачков к образованию яиц, не снизив их репродукционную поведенческую активность.

\section{Обсуждение}

За всю историю развития угольной промышленности в г. Воркуте (с 1933 г.) своего максимума (22 300 тыс. т (Гудованый, 2011 б)) добыча угля в регионе достигла в 1988 г. В 1994 г. на 12 шахтах в Воркутинском районе добыли 8859 тыс. т угля (Горнодобывающие предприятия..., 1995), а в 2009 г. на оставшихся 5 шахтах - только 7551 тыс. т (Гераймович и др., 2010). Эти факты демонстрируют снижение активности промышленности в регионе исследований в последние десятилетия, а 
значит, уменьшение влияния на водоемы загрязняющих веществ, поступающих со стороны воркутинской промышленной зоны с атмосферными осадками.

Тренды динамики температуры воздуха в г. Воркуте за 1960-2009 гг. свидетельствуют о тенденции потепления климата в регионе в годы изучения Харбейских озер. Повышенные летние температуры как напрямую, так и косвенно влияли на популяции и сообщества гидробионтов в исследованных озерах. При анализе воздействия этого фактора на сообщества Харбейских озер следует учитывать, что погодные условия отдельных лет, в которые проводились исследования, были даже контрастны. За все годы изучения только 20092012 гг. не характеризовались наибольшими или наименьшими значениями температур или количества осадков за год, а были средними по метеорологическим показателям.

Виды и популяции гидробионтов, обитающие на севере в условиях пониженных температур, проявляют в жизненных циклах адаптационные особенности (например, Sarvala, 1979; Hebert et al., 2007). Подавляющая часть фауны беспозвоночных Харбейских озер представлена азональными видами (Фефилова, 2002; Fefilova et al., 2012), некоторые таксоны, например гарпактицид, распространены только на севере и, следовательно, холодолюбивы (Fefilova, 2007; Fefilova et al., 2008). В воркутинской тундре последние, тем не менее, должны быть акклиматизированы к высокой изменчивости метеорологических условий и обладать так называемыми динамическими экологическими оптимумами (Вербицкий, 2008), так как присущие резкоконтинентальному климату широкие амплитуды колебаний сезонных внутри сезонных и межгодовых температур не утрачивают в регионе исследований своего значения, несмотря на повышение средних показателей
(Гудованый, 2011a). Устойчивость к резким колебаниям температур гидробионтных видов обеспечивает в Харбейских озерах сохранение в целом видового состава сообществ по истечении более 40 лет (табл. 6).

Негативное воздействие повышенных температур на физиологическое состояние гидробионтов в исследованных озерах было обнаружено при сравнении популяций гарпактицид в различные годы при контрастных температурах воды. Хотя установлено (Fefilova, 2007), что в водоемах севера России самки с яйцевыми мешками P. schmeili и B. z. komi встречаются при температуре воды до $20,5^{\circ} \mathrm{C}$, M. duthiei - до $22^{\circ} \mathrm{C}$, M. schmeili - до $18,7^{\circ} \mathrm{C}$, наши наблюдения позволили предположить, что оптимальные для размножения этих видов пределы колебаний этого показателя расположены ниже. Однако повышение температуры воды вследствие потепления климата не достигло в Харбейских озерах катастрофического для популяций холодолюбивых гарпактицид уровня. Состав и видовая структура этих ракообразных в экосистемах сохранялась в 1960-2000-е гг.

Структурные характеристики водных сообществ являются хорошими индикаторами изменений функционирования экосистем: динамики скорости биотических процессов, баланса деструкции-продукции (Beznosov, Suzdaleva, 2004; Лазарева, 2010; Dupuis, Hann, 2009; Максимов и др., 2012 и др.) и так называемого термального эвтрофирования (Веригин, 1977). Как и в олиго- и мезотрофных водоемах средних широт (Андроникова, 1980, 1996; Лазарева, 2010; Максимов, 2012), в Харбейских озерах наблюдались, очевидно связанные с глобальной динамикой температуры, положительные тренды общих количественных показателей зоопланктона (табл. 6), которые сопровождались ростом обилия одних видов и снижением - других. Причем преимущество 
Таблица 6. Оценка многолетних изменений характеристик сообществ гидробионтов Харбейских озер

\begin{tabular}{|c|c|c|}
\hline Показатель и направление его изменений & $\begin{array}{c}\text { Оценка } \\
\text { изменений } \\
\text { состояния } \\
\text { экосистемы }\end{array}$ & Литература \\
\hline \multicolumn{3}{|c|}{ Изменения в 2000-е гг. относительно 1960-х } \\
\hline Число видов ракообразных в зоопланктоне - без изменений & + & Нет \\
\hline $\begin{array}{l}\text { Состав планктонных фаун (по коэффициенту Съеренсена) - без } \\
\text { изменений }\end{array}$ & + & Нет \\
\hline Уменьшение коэффициентов трофии $(E, E / O)^{* *}$ & + & $\begin{array}{l}\text { Андронниква, 1996; } \\
\text { Лазарева, } 2010 \text { и др. }\end{array}$ \\
\hline $\begin{array}{l}\text { Появление видов-индикаторов мезо- и эвтрофных условий } \\
\text { (P. euryptera, D. cucullata, B. nilsoni) }\end{array}$ & - & $\begin{array}{l}\text { Лазарева, Смирнова, 2008; } \\
\text { Лазарева, 2010; Смирнов, } \\
2010\end{array}$ \\
\hline $\begin{array}{l}\text { Появление или увеличение доли таксонов-индикаторов } \\
\text { олиготрофных условий (Bythotrephes, Daphnia, B. longispina) }\end{array}$ & + & $\begin{array}{l}\text { Андроникова, 1996; } \\
\text { Dupuis, Наnn, 2009; } \\
\text { Лазарева, } 2010\end{array}$ \\
\hline $\begin{array}{l}\text { Уменьшение относительной численности видов-индикаторов } \\
\text { мезо- и эвтрофных условий (K. quadrata и B. longirostris) }\end{array}$ & + & $\begin{array}{l}\text { Андроникова, 1996; } \\
\text { Смирнов, } 2010 \text { и др. }\end{array}$ \\
\hline $\begin{array}{l}\text { В составе супердоминантов по биомассе в зоопланктоне вместо } \\
\text { коловраток только ракообразные }\end{array}$ & + & $\begin{array}{l}\text { Рогозин, 2000, 2001; } \\
\text { Strecker et al., } 2004\end{array}$ \\
\hline $\begin{array}{l}\text { Отношение численности ракообразных к численности } \\
\text { коловраток - без изменений* }\end{array}$ & + & $\begin{array}{l}\text { Strecker et al., } 2004 \\
\text { Лазарева, } 2010\end{array}$ \\
\hline $\begin{array}{l}\text { Увеличение численности зоопланктона в конце июля, начале } \\
\text { августа * }\end{array}$ & - & $\begin{array}{l}\text { Андроникова, 1980, 1996; } \\
\text { Beznosov, Suzdaleva, 2004; }\end{array}$ \\
\hline $\begin{array}{l}\text { Увеличение биомассы зоопланктона в конце июля, начале } \\
\text { августа * }\end{array}$ & - & Лазарева, 2010 и др. \\
\hline Величины константы $a$ не изменились** & + & $\begin{array}{l}\text { Рогозин, 2000, 2001; } \\
\text { Лазарева, Смирнова, } 2008\end{array}$ \\
\hline $\begin{array}{l}\text { Лимнологический тип водоема по биомассе зообентоса - без } \\
\text { изменений* }\end{array}$ & + & Китаев, 2007 \\
\hline $\begin{array}{l}\text { Изменение доли доминирующих групп в общей биомассе } \\
\text { бентоса - незначительное* }\end{array}$ & + & Голубков, 2012 \\
\hline $\begin{array}{l}\text { Структура доминирующих комплексов в макрозообентосе - } \\
\text { без изменений* }\end{array}$ & + & Нет \\
\hline Доля Oligochaeta в численности зообентоса - без изменений* & + & $\begin{array}{l}\text { Beznosov, Suzdaleva, 2004; } \\
\text { Moiseenko et al, 2006; } \\
\text { Тимакова и др., } 2011\end{array}$ \\
\hline $\begin{array}{l}\text { Соотношение биомасс хищного и мирного бентоса - без } \\
\text { изменений* }\end{array}$ & + & Яковлев, 2005 \\
\hline Увеличение средней численности бентоса & - & Яковлев, 2005 \\
\hline
\end{tabular}

\begin{tabular}{l|c|c|}
\hline \multicolumn{2}{|c|}{ Изменения в 2000-е гг. относительно 1990-х } \\
\hline $\begin{array}{l}\text { Информационный индекс сапробности Oligochaeta - без } \\
\text { изменений* }\end{array}$ & + & Попченко, 1987 \\
Уменьшение средней биомассы зообентоса* & + & Яковлев, 2005 \\
Уменьшение средней индивидуальной массы особей в \\
зообентосе*
\end{tabular}

Примечание: “+” свидетельствует о стабильном состоянии экосистемы, или направление изменений обычно связывают с реолиготрофикацией; “-” указывает, что изменения обычно связывают с эвтрофированием; * характеристика только оз. Большой Харбей; ** характеристика только озер Большой Харбей и Головка. 
получали виды-индикаторы олиготрофных условий: C. unicornis, B. longispina, C. scutifer, а снижали численность виды-индикаторы мезо- и эвтрофных условий: K. quadrata, B. longirostris (табл. 2). Очевидно, что, несмотря на повышение продуктивности экосистемы озер в 2000-е гг., ее современное состояние ближе к уровню олиготрофного водоема по сравнению с 1960-ми гг.

Начиная с 1999 г. регулярное присутствие в зоопланктоне озер Большой Харбей и Головка малочисленных теплолюбивых (Пидгайко, 1984) P. euryptera и D. cucullata, индикаторов мезо- и эвтрофных условий (Андронникова, 1996) сменилось появлением в 2012 г. индикатора олиготрофных условий (Андронникова, 1996) - Bythotrephes sp. и, следовательно, носило колебательный характер.

Bythotrephes sp. - крупный, подвижный и контрастно окрашенный хищный рачок. Его появление в водоемах связывают со снижением количества рыб планктофагов, объектом питания которых он служит, и/ или повышением количества мелких планктонных животных, служащих Bythotrephes пищей. Эти факты, в свою очередь, могут свидетельствовать также об ухудшении качества среды обитания (Крылов и др., 2004) или потеплении (Manca, DeMott, 2009; Guilizzoni et al, 2012).

Неоднозначно можно оценить, чем обусловлено наблюдаемое в Харбейских озерах повышение обилия доминирующих в планктоне видов Daphnia. В 2000-х гг. в озерах встречались те же виды дафний, что и в 1960-х (за исключением упомянутой ранее D. cucullata), и их численность в сходные сроки отбора проб на современном этапе увеличилась (табл. 2). Направленное из года в год возрастание роли дафний в сообществах могло быть связано с переходом экосистемы на более высокий уровень трофности (Андронникова, 1980; O’Brien et al, 2005; Tsugeki et al.,
2009; Guilizzoni et al, 2012; Лазарева, Соколова, 2013) и ослаблением пресса рыб (Tsugeki et al., 2009) или, напротив, с еe реолиготрофикацией (Dupuis, Hann, 2009). Повышение температуры может вызвать отрицательные явления в природных весенних популяциях Daphnia, связанные с ограничениями вертикального распределения животных, дегенерацией партеногенетических яиц, уменьшением скорости фильтрации и плодовитости (Дубовская, 2009). Результатом этих явлений становятся обусловленные потеплением изменения в сезонной динамике популяций рачков (например, Straile, 2002; Wagner, Adrian, 2009; Carter, Schindler, 2012). При отсутствии сезонных наблюдений Daphnia в Харбейских озерах в 1990-х и 2000-х гг. затруднительно судить об истинной причине различий в количестве этих ветвистоусых в сходные сроки на разных этапах изучения. Но, вероятнее всего, эти различия не обусловлены эвтрофированием экосистемы.

Отсутствие сравнительных сезонных наблюдений беспозвоночных Харбейских озер не позволяет нам судить о межгодовом изменении сроков наступления фенологических событий в популяциях и сообществах. В 1968, 1969 гг. максимумы численности и биомассы планктонных коловраток и ракообразных приходились на вторую половину августа (Барановская, 1976), и значения этих наибольших показателей оказались выше по сравнению со средними величинами 2009, 2010, 2012 гг. Следовательно, увеличение на современном этапе изучения обилия зоопланктона в озерах за счет нескольких массовых видов и групп и отсутствие при этом перестроек в структуре сообществ (табл. 6) можно объяснить связанным с потеплением сдвигом во времени пиков численности и биомассы планктонных животных, несовпадением сроков их наступления в 1960-е и 2000-е гг. 
В качестве отклика на изменения климата такие явления наблюдались в других водоемах (Wagner, Adrian, 2009; Carter, Schindler, 2012; Лазарева, Соколова, 2013).

Макрозообентос относится к наиболее консервативным элементам биоты, влияние на бентос климатических факторов осуществляется опосредованно через общее повышение продуктивности водоема (Максимов, 2012). В крупных озерных экосистемах даже при антропогенном влиянии в течение десятилетий усредненные по акватории показатели развития зообентоса сохраняются, нивелируя локальные изменения в прибрежной зоне (Тимакова и др., 2011). Тем не менее современное состояние донных сообществ отличается от их состояния в доиндустриальные периоды развития регионов (Беляков, Скворцов, 1994; Тимакова и др., 2011; Ильяшук, 2002; Moiseenko et al, 2006 и др.). Экологическая стабильность наблюдалась в состоянии зообентоса Харбейских озер в течение более чем 40 лет (1965-2012 гг.). Одним из ее критериев (Голубков, 2012) являлась неизменность доли доминантов по биомассе в донном сообществе. К современному периоду изучения озер по сравнению с 1960-ми гг. общая доля Chironomidae, Oligochaeta и Mollusca в биомассе макрозообентоса уменьшилась всего на 12 $\%$, что свидетельствует об отсутствии значимых изменений в экосистеме (табл. 6). Применяя другие показатели изменения трофности, связанные со структурными и количественными характеристиками зообентоса (Попченко, 1987; Яковлев, 2000; Китаев, 2007), мы определили, что оз. Большой Харбей, как и в 1960-е гг., сохраняет статус мезотрофного водоема (табл. 6). Такие показатели, как увеличение средней численности доминирующих групп и бентоса в целом (табл. 6), указывают скорее на связанные с дополнительным поступлением тепла различия в сезонной дина- мике количественных показателей развития зообентоса между сравниваемыми периодами, чем на повышение трофности водоема.

Умеренное повышение трофности северных водоемов не приводит к катастрофической деградации экосистем (Яковлев, 2005). Они приспосабливаются за счет возрастания численности организмов, обеспечивающих экосистемам более полное использование энергии (Левченко, Старобогатов, 1990).

К сожалению, хотя на всех этапах изучения донной фауны Харбейских озер были получены данные о количественных показателях развития беспозвоночных, но сведения о видовом составе зообентоса были неполные. Это существенно ограничило возможность оценки динамики состояния экосистемы с точки зрения анализа изменений фаунистического разнообразия зообентоса.

\section{Заключение}

Экологическое состояние экосистемы Харбейских озер в 1960-е гг. по ряду показателей, в том числе продукционным, соответствовало мезотрофному статусу (Продуктивность озер..., 1976). Оно определялось региональными природно-климатическими условиями и, возможно, загрязнением атмосферными осадками со стороны зоны угольных шахт. Динамика сообществ гидробионтов исследованных озер в течение более чем 40-летнего периода происходила на фоне снижения интенсивности промышленной деятельности в регионе и потепления климата. В основном озере Харбейской системы к 2000м гг. по сравнению с 1960-ми наблюдалось понижение численности видов-индикаторов мезо- и эвтрофных условий в планктонном сообществе; численность некоторых таксонов, характерных для олиготрофных условий, возросла. Эти направленные изменения в экосистеме свидетельствовали о понижении 
уровня трофности. Кроме того, современный статус оз. Большой Харбей приближался к олиготрофному по: преобладанию по числу в планктонной фауне видов-индикаторов олиготрофных условий, высокой роли ракообразных в зоопланктоне относительно роли коловраток, распределению биомассы в планктонном сообществе. По развитию зообентоса оз. Большой Харбей по-прежнему характеризовалось как мезотрофная лимническая система. Состояние придаточных озер Харбейской системы было различным, и в 2000 -е гг. показатели развития сообществ в них соответствовали уровню от олиго- до эвтрофного.

Признаки реолиготрофикации обследованных озер на современном этапе наблюдались на фоне повышения количественных характеристик сообществ, которые, что нель- зя исключать, были следствием изменения сроков наступления пиков численности и биомассы гидробионтов и других фенологических явлений в сообществах под влиянием потепления климата.

\section{Благодарности}

Мы благодарим Е.К. Роговцову и Т.А. Кондратьеву за идентификацию видов таксонов Coleoptera и Chironomidae, B.P. Алексеева - за предоставленные пробы Harpacticoida, а также коллектив экоаналитической лаборатории Института биологии Коми НЦ Уральского отделения РАН за определение химического состава воды. Исследования Харбейских озер были выполнены в рамках проектов: совместного Уральского и Сибирского отделений PAH (№№ 12C4-1011 и 8), РФФИ (№ 11-0500246-а) и 12-4-7-004-АРКТИКА.

\section{Список литературы}

1. Андронникова И.Н. (1980) Изменения в сообществе зоопланктона в связи с процессом эвтрофирования. В: Андронникова И.Н. (ред.) Эвтрофирование мезотрофного озера (по материалам многолетних наблюдений на оз. Красном). Л.: Наука, с. 78-99.

2. Андронникова И.Н. (1996) Структурно-функциональная организация зоопланктона озерных экосистем разных трофических типов. СПб.: Наука, 190 с.

3. Балушкина Е.В., Винберг Г.Г. (1979) Зависимость между массой и длиной тела планктонных ракообразных. В: Экспериментальные и полевые исследования биологических основ продуктивности озер. Л.: Зоол. ин-т АН СССР, с. 58-79.

4. Барановская В.К. (1976) Зоопланктон Харбейских озер Большеземельской тундры. В: Винберг Г.Г., Власова Т.А. (ред.) Продуктивность озер восточной части Большеземельской тундры. Л.: Наука, с. 90-101.

5. Барановская В.К. (1978) Crustacea (Систематический список беспозвоночных из водоемов Большеземельской тундры). В: Гецен М.В. (ред.) Флора и фауна водоемов Европейского Севера. Л.: Наука, с. 174-177.

6. Беляков В.П., Скворцов В.В. (1994) Макро- и мейобентос, их продукция. В: Драбкова В.Г., Трифонова И.С. (ред.) Особенности структуры экосистем озер Крайнего Севера (на примере озер Большеземельской тундры). СПб: Наука, с. 183-203.

7. Вербицкий В.Б. (2008) Понятие экологического оптимума и его определение у пресноводных пойкилотермных животных. Журн. общ. биологии 69 (1): 44-56.

8. Веригин Б.В. (1977) О явлении термического евтрофирования водоемов. Гидробиол. журн. 13 (5): 98-105. 
9. Власова Т.А. (1976) Гидрологические и гидрохимические условия биологического продуцирования в озерах Харбейской системы. В: Винберг Г.Г., Власова Т.А. (ред.) Продуктивность озер восточной части Большеземельской тундры. Л.: Наука, с. 6-26.

10. Гераймович С.Л., Бушенев А.А., Галиев И.Ф., Гусар Н.И., Завьялов Я.Б. (2010) Состояние и использование недр. В: Некипелова М.В. (ред.) Государственный доклад «О состоянии окружающей природной среды Республики Коми в 2009 году»/ Министерство природных ресурсов и охраны окружающей среды Республики Коми. Сыктывкар: ГУ «ТФИ РК», с. 27-29.

11. Голубков С.М. (2012) Использование принципов «Водной директивы Европейского союза» для оценки состояния биологических сообществ. В: Алимов А.Ф., Голубков С.М. (ред.) Динамика биологического разнообразия и биоресурсов континентальных водоемов. СПб.: Наука, с. 258-266.

12. Горнодобывающие предприятия, разрабатывающие полезные ископаемые (1995) В: Таскаев А.И. (ред.) Государственный доклад «О состоянии окружающей природной среды Республики Коми в 1994 году»/ Министерство природных ресурсов и охраны окружающей среды Республики Коми и Институт биологии Коми НЦ УрО РАН. Сыктывкар, с. 87-90.

13. Гудованый О.А. (2011а) Условия формирования климата Воркуты. Основные элементы климата. В: Гецен М.В. (ред.) Воркута - город на угле, город в Арктике. Второе дополненное и переработанное издание. Сыктывкар: Коми республиканская типография, с. 26-45.

14. Гудованый О.А. (2011б) Из истории открытия углей. Цена освоения угля. В: Гецен М.В. (ред.) Воркута - город на угле, город в Арктике. Второе дополненное и переработанное издание. Сыктывкар: Коми республиканская типография, с. 229-241.

15. Даувальтер В.А. (2004) Влияние воздушных выбросов Воркутинского промышленного района на химический состав озерных донных отложений. Вод. ресурсы 31 (6): 721-725.

16. Даувальтер В.А., Хлопцева Е.В. (2008) Гидрологические и гидрохимические особенности озер Большеземельской тундры. Вестн. МГТУ 1 (3): 407-414.

17. Дубовская О.П. (2009) Не связанная с хищниками смертность планктонных ракообразных, ее возможные причины (обзор литературы). Журн. общ. биологии 70 (2): 168-192.

18. Зверева О.С. (1966) Бентос и общие вопросы гидробиологии Вашуткиных озер. В: Гидробиологическое изучение и рыбохозяйственное освоение озер Крайнего Севера СССР. М.: Наука, с. 112-137.

19. Зинченко Т.Д. (2011) Эколого-фаунистическая характеристика хирономид (Diptera, Chironomidae) малых рек бассейна средней и нижней Волги (Атлас). Тольятти: Касандра, $258 \mathrm{c}$.

20. Ильяшук Б.П. (2002) Реликтовые ракообразные в условиях длительного загрязнения субарктического оз. Имандра (результаты наблюдений за период 1930-1998 гг.). Экология 3: 215-220.

21. Китаев С.П. (2007) Основы лимнологии для гидробиологов и ихтиологов. Петрозаводск: Карельский НЦ РАН, 395 с.

22. Крылов П.И., Большагин П.В., Панов В.Е., Быченков Д.Е., Науменко Е.Н. Полунина Ю.Ю. (2004) Инвазии хищных планктонных Cladocera и возможные причины их успеха. В: Алимов А.Ф., Голубков С.М. (ред.) Биологические инвазии в водных и наземных экосистемах. М.: Товарищество научных изданий КМК, с. 100-130.

$$
-261-
$$


23. Кутикова Л.А. (1978) Rotatoria (Систематический список беспозвоночных из водоемов Большеземельской тундры). В: Гецен М.В. (ред.) Флора и фауна водоемов Европейского Севера. Л.: Наука, с. 168-170.

24. Лазарева В.И. (2010) Структура и динамика зоопланктона Рыбинского водохранилища. М.: Товарищество науч. изданий КМК, 183 с.

25. Лазарева В.И., Смирнова С.М. (2008) Ракообразные и коловратки. В: Лазарева В.И. (ред.) Состояние экосистемы озера Неро в начале XXI века. М.: Наука, с. 175-210.

26. Лазарева В.И., Соколова Е.А. (2013) Динамика и фенология зоопланктона крупного равнинного водохранилища: отклик на изменение климата. Успехи современной биологии 133 (6): 564-574.

27. Лакин Г.Ф. (1990) Биометрия. М.: Высшая школа, 352 с.

28. Левченко В.Ф., Старобогатов Я.И. (1990) Сукцессионные изменения и эволюция экосистем (некоторые вопросы эволюционной экологии). Журн. общей биологии 51 (5): 69-73.

29. Лоскутова О.А. (2002) Бентос озерно-речных систем восточно-европейской тундры В: Таскаев А.И. (ред.) Возобновимые ресурсы водоемов Большеземельской тундры. Тр. Коми научного центра УрО РАН, № 169. Сыктывкар, с. 44-57.

30. Мажитова Г.Г., Каверин Д.А. (2007) Динамика глубины сезонного протаивания и осадки поверхности почвы на площадке циркумполярного мониторинга деятельного слоя (CALM) в Европейской части России. Криосфера Земли 11 (4): 20-30.

31. Макрушин А.В. (1974) Биологический анализ качества вод. Л.: ЗИН АН СССР, 60 с.

32. Максимов А.А. (2012) Многолетняя изменчивость климатических факторов и динамика сообществ донных животных. В: Алимов А.Ф., Голубков С.М. (ред.) Динамика биологического разнообразия и биоресурсов континентальных водоемов. СПб.: Наука, с. 126-138.

33. Максимов А.А., Березина Н.А., Голубков С.М., Умнова Л.П. (2012) Многолетние климатически обусловленные изменения продуктивности экосистемы северного озера В: Алимов А.Ф., Голубков С.М. (ред.) Динамика биологического разнообразия и биоресурсов континентальных водоемов. СПб: Наука, с. 138-144.

34. Методика изучения биогеоценозов внутренних водоемов (1975) М.: Наука, 240 с.

35. Методические рекомендации по сбору и обработке материалов при гидробиологических исследованиях на пресноводных водоемах. Зоопланктон и его продукция. (1984) Л.: Гос. НИИ озер. и реч. рыб. хоз-ва, 34 с.

36. Монаков А.В. (1998) Питание пресноводных беспозвоночных. М.: Ин-т проблем экологии и эволюции РАН, 319 с.

37. Набережный А.И., Ирмашева С.Г. (1980) Соотношение размеров и массы тела у гарпактицид (Crustacea, Harpacticoida). Известия АН Молдавской CCP 4: 75-76.

38. Определитель зоопланктона и зообентоса пресных вод Европейской России. Т. 1: Зоопланктон (2010). Алексеев В.Р., Цалолихин С.Я. (ред.) М.: Товарищество науч. изданий КМК, $495 \mathrm{c}$.

39. Определитель пресноводных беспозвоночных Европейской части СССР (1977). Кутикова Л.Я., Скоробогатов Я.И. (ред.). Л.: Гидрометеоиздат, 510 с.

40. Определитель пресноводных беспозвоночных России и сопредельных территорий. Т. 4. Высшие насекомые. Двукрылые (1999). Нарчук Э.П., Туманов Д.В. (ред.). СПб.: Наука, 998 с. 
41. Панин Г.Н., Соломонова И.В., Выручалкина Т.Ю. (2009) Климатические тенденции в средних и высоких широтах северного полушария. Водные ресурсы 36 (6): 743-756.

42. Пидгайко М.Л. (1978) Зоопланктоценозы водоемов различных почвенно-климатических зон. Изв. Гос. НИИ озер. и реч. рыб. хоз-ва 135: 3-109.

43. Пидгайко М.Л. (1984) Зоопланктон водоемов Европейской части СССР. М.: Наука, 208 с.

44. Попова Э.И. (1976) Бентос оз. Б. Харбей и его продукция. В: Винберг Г.Г., Власова Т.А. (ред.) Продуктивность озер восточной части Большеземельской тундры. Л.: Наука, c. 101-103.

45. Попченко В.И. (1987) Водные малощетинковые черви (Oligochaeta liminicola) Севера Европы. Л.: Наука, 287 с.

46. Продуктивность озер восточной части Большеземельской тундры. (1976). Л.: Наука, 147 с.

47. Рогозин А.Г. (2000) Особенности структурной организации зоопланктонного сообщества в озерах разного трофического статуса. Видовые популяции. Экология 6: 438-443.

48. Рогозин А.Г. (2001) Об изменении скорости сукцессии водных экосистем. Изв. Челябинск. науч. центра 4 (13): 73-76.

49. Смирнов Н.Н. (2010) Историческая экология пресноводных зооценозов. М.: Товарищество науч. изданий КМК, 225 с.

50. Тимакова Т.М., Сабылина А.В., Т.Н. Полякова, Сярки М.Т., Теканова Е.В., Чекрыжева Т.А. (2011) Современное состояние экосистемы Онежского озера и тенденции ее изменения за последние десятилетия. Труды Карельского научного центра РАН 4: 42-49.

51. Фефилова Е.Б. (2002) Изученность планктонной фауны тундровых озер. В: Таскаев А.И. (ред.) Возобновимые ресурсы водоемов Большеземельской тундры. Сыктывкар: Коми научный центр УрО Российской АН, с. 33-43.

52. Хохлова Л.Г. (2014) Ретроспективный анализ химического состава воды озер Большеземельской тундры (Большой Харбей и Головка). Известия Коми научного центра УрО РАН 1 (17): 19-26.

53. Шитиков В.К., Розенберг Г.С., Зинченко Т.Д. (2005) Количественная гидроэкология: методы, критерии, решения. Кн. 1. М.: Наука, 281 с.

54. Яковлев В.А. (2003) Зависимость средних масс тела особей в сообществах пресноводного макрозообентоса от условий среды обитания. Биология внутренних вод 3: 3-13.

55. Яковлев В.А. (2005) Пресноводный зообентос северной Фенноскандии (разнообразие, структура и антропогенная динамика). Ч.1, Ч.2. Апатиты: Кольский научный центр РАН, $161 \mathrm{c.}, 145 \mathrm{c}$.

56. Adrian R., O’Reilly C.M., Zagarese H., Baines S.B., Hessen D.O., Keller W., Livingstone D.M., Sommaruga R., Straile D., Donk E.V., Weyhenmeyer G.A., Winder M. (2009) Lakes as sentinels of climate change. Limnol. Oceanogr. 54 (6, part 2): 2283-2297.

57. Archegova I.B. (2007) Thermal regime of Tundra soils under reclamation and restoration of natural vegetation. Eurasian Soil Sci. 40 (8): 854-859.

58. Belshe E.F., Schuur E. A. G., Bolker B. M. (2013) Tundra ecosystems observed to be $\mathrm{CO} 2$ sources due to differential amplification of the carbon cycle. Ecology Letters 16: 1307-1315.

59. Beznosov V.N., Suzdaleva V.L. (2004) Potential changes in aquatic biota in the period of global climate warming. Water Resources 31 (4): 459-464. 
60. Brinkhurst R.O., Kennedy C.R. (1965) Studies on the biology of the Tubificidae in polluted stream. J. Anim. Ecol. 34: 429 - 443.

61. Brooks S. J., Langdon P.G., Heiri O. (2007) The identification and use of palearctic Chironomidae larvae in paleoecology. QRA. Technical Guide, № 10. London: Quaternary Research Association, 265 p.

62. Carter J.L., Schindler D.E. (2012) Responses of zooplankton populations to four decades of climate warming in lakes of Southwestern Alaska. Ecosystems 15: 1010-1026.

63. Dupuis A.P., Hann B.J. (2009) Climate change, diapause termination and zooplankton population dynamics: an experimental and modeling approach. Freshwater Biology 54: 221-235.

64. Fefilova E. (2007) Seasonal development of harpacticoid copepods in the North-East of European Russia. Fundamental and Applied Limnology/ Archiv für Hydrobiologie 170 (1): 65-75.

65. Fefilova E.B. (2011) The state of a river in Pechora Basin after an oil spill: assessment of changes in zooplankton community. Water Resources 38 (5): 637-649.

66. Fefilova E.B., Kononova O.N., Dubovskaya O.P., Khokhlova L.G. (2012) The current state of zooplankton in the lake system of Bol'shezemel'skaya Tundra. Inland Water Biology 5 (4): 333-341.

67. Fefilova E.B., Loskutova O.A., Pestov S.V. (2008) Micro-benthic crustacean communities in tundra lakes of North-East European Russia. Aquatic Ecology 42: 449-461.

68. Finogenova N.P. (1996) Oligochaeta communities at the mouth of the Neva and their relationship to anthropogenic impact. Hydrobiologia 334: 185 - 191.

69. Guilizzoni P., Levine S.N., Manga M., Marchetto A., Lami A., Ambrosetti W., Brauer A., Gerli S., Carrara E. A., Rolla A., Guilizzoni L., Vignati D. A. L. (2012) Ecological effects of multiple stressors on a deep lake (Lago Maggiore, Italy) integrating neo and palaeolimnological approaches J. Limnol. 71(1): 1-22.

70. Hebert P. D. N., Rowe C.L., Adamowicz S.J. (2007) Life at low temperatures: A novel breedingsystem adjustment in a polar cladoceran. Limnol. Oceanogr. 52(6): 2507-2518.

71. Hickling R., Roy D.B., Hill J.K., Fox R., Thomas C.D. (2006) The distributions of a wide rang of taxonomic groups are expanding polewards. Global Change Biology 12: 450-455.

72. Jeppersen E., Sondergaard M., Jensen J.P., Havens K., Anneville O., Carvalho L., Coveney M. F., Deneke R., Dokulil M.T., Foy B., Gerdeaux D., Hampton S.E., Hilt S., Kangur K., Kohler J., Lammens E., Lauridsen T. L., Manca M., Miracle R., Moss B., Noges P., Persson G., Phillips G., Portielje R., Romo S., Schelske C.L., Straile D., Tatrai I., Willen E., Winder M. (2005) Lake responses to reduced nutrient loading - an analysis of contemporary long-term data from 35 case studies. Freshwater Biology 50: 1747-1771.

73. Lafont M. (1984) Oligochaete communities as biological descriptors of pollution in the fine sediments of rivers. Hydrobiologia 115: 127 - 129.

74. Lenoir J., Gegout J., Marquet P., de Ruffray P., Brisse H. (2006) A significant upwardrange of taxonomic groups are expanding polewards. Global Change Biology 12: 450-455.

75. Mancaa M., DeMott W.R. (2009) Response of the invertebrate predator Bythotrephes to a climatelinked increase in the duration of a refuge from fish predation. Limnol. Oceanogr. 54 (6, part 2): $2506-2512$.

76. Milbrink G. (1980) Oligochaete communities in pollution biology: the European: situation with special reference to lakes in Scandinavia. In: Aquatic Oligochaeta Biology. N-Y.- London: Plenum press, p. $433-455$. 
77. Moiseenko T.I., Voinov A.A., Megorsky V.V., Gashkina N.A., Kudriavtseva L.P., Vandish O.I., Sharov A.N., Sharova Yu., Koroleva I.N. (2006) Ecosystem and human health assessment to define environmental management strategies: The case of long-term human impacts on an Arctic lake. Science of the Total Environment 369: 1-20.

78. O’Brien W.J., Barfield M., Bettez N., Hershey A.E., Hobbie J.E., Kipphut G., Kling G., Miller M.C. (2005) Long-term response and recovery to nutrient addition of a partitioned arctic lake. Freshwater Biol. 50: 731-741.

79. Rautio M., Korhola A. (2002) Effects of ultraviolet radiation and dissolved organic carbon on the survival of subarctic zooplankton. Polar. Biol. 25: 460-468.

80. Richardson A. J. (2008) In hot water: zooplankton and climate change. ICES Journal of Marine Science 65: 279-295.

81. Rosset V., Lehman A., Oertli B. (2010) Warmer and richer? Predicting the impact of warming on species richness in small temperate water bodies. Global Change Biology doi: 10.1111/j.13652486.2010.02206.x.

82. Ruttner-Kolisko A. (1977) Suggestions for biomass calculation of plankton rotifers. Arch. Hydrobiol. Ergebn. Limnol. 8: 71-78.

83. Särkkä J. (1994) Lacustrine, profundal meiobenthic oligochaetes as indicators of trophy and organic loading. Hydrobiologia 278: 231-241.

84. Sarvala J. (1979) A parthenogenetic life cycle in a population of Canthocamptus staphylinus (Copepoda: Harpacticoida). Hydrobiologia 62 (2): 113-129.

85. Serreze M.C., Walsh J.E., Chapin III F.S., Osterkamp T., Dyurgerov M., Romanovsky V., Oechel W.C., Morrison J., Zhang T., Barry R.G. (2000) Observational evidence of recent change in the northern high-latitude environment. Climatic Change 46: 156-207.

86. Sladecek V. (1973) System of water quality from the biological point of view. Arch. Hydrobiol. Ergehnisse der Limnologie 7: 218.

87. Sørensen T. (1948) A method of establishing groups of equal amplitude in plant sociology based on similari of species content and its application to analises of the vegetation on Danish commons. Biol. Skr. 5: 1-34.

88. Straile D. (2002) North Atlantic Oscillation synchronizes food-web interactions in central European lakes. Proc. Roy. Soc. Lond. 269: 391-395.

89. Strecker, A. L., Cobb T. P., Vinebrooke R. D. (2004) Effects of experimental greenhouse warming on phytoplankton and zooplankton communities in fishless alpine ponds. Limnology and Oceanography 49: 1182-1190.

90. The Chironomidae. The biology and ecology of non-biting midges (1995) Armitage P., Cranston P.S., Pinder L.C.V. (eds.). London: Chapman \&Hall, 572 p.

91. Timm T. (2009) A guide to the freshwater Oligochaeta and Polychaeta of Northern and Central Europe. Lauterbornia 66: 1-235.

92. Tsugeki N., Oda H., Urabe J. (2003) Fluctuation of the zooplankton community in Lake Biwa during the 20th century: a paleolimnological analysis. Limnology 4:101-107.

93. Verta M., Mannio J., Iivonen P., Hirvi J.-P., Jarvinen O., Piepponen S. (1990) Trace metals in Finnish headwater lakes effects of acidification and airborne load. In: Kauppi P., Anttila R., Kenttamies K. (eds.) Acidification in Finland. Berlin: Springer-Verlag, p. 883-920. 
94. Wagner C., Adrian R. (2009) Exploring lake ecosystems: hierarchy responses to long-term change? Global Change Biology 15: 1104-1115.

95. Cironomidae of the Holarctic region. Keys and diagnoses. Part 1. Larvae. (1983-1989) Wiederholm T. (Ed.) Ent. Scand. Suppl. 19: 1-457. 